$$
\text { مونودراما المسرح السعودى الروية }
$$

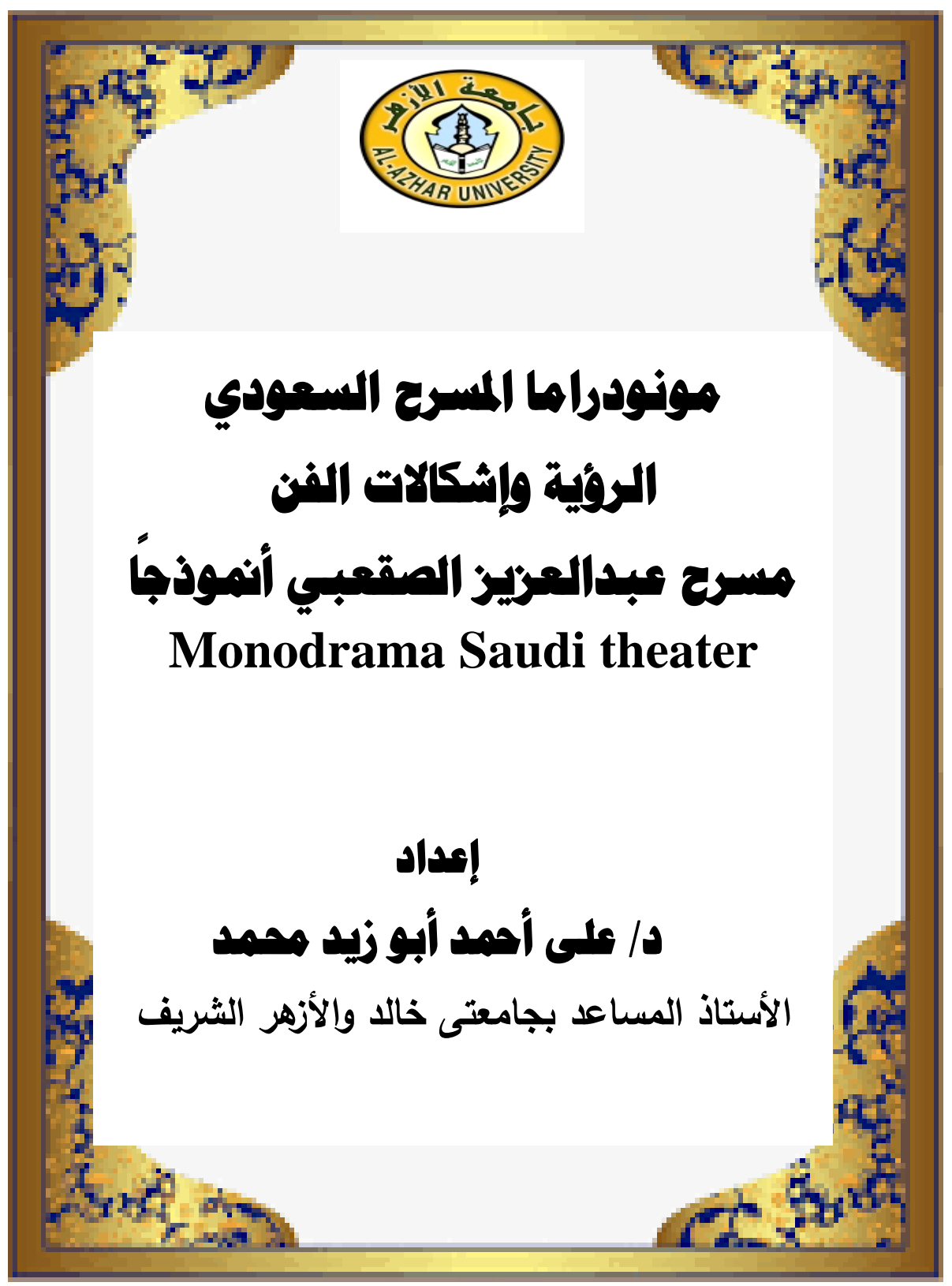

\title{
$01 \varepsilon$
}

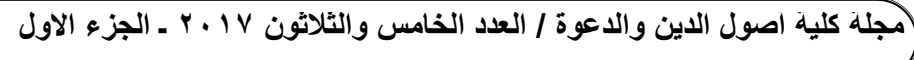




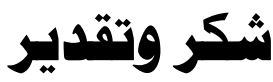

楼溇棌

\section{هذا البحث تم دعمه هن خلال}

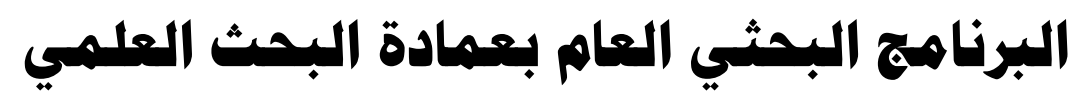

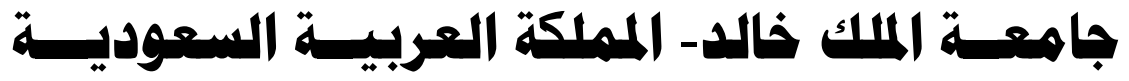

$$
\text { بالرقم/G.R.P-XXX-38) }
$$




$$
\text { مونودراما المسرح السودى الروئية }
$$

\section{الإقدهة}

الحمد لله رب العالمين ، والصلاة والسلام على النبي الكريم ، وعلى آله وصحبه أجمعين لمبه ويعد - (n)

فالمونودراما أو مسرح الشخص الواحد (One man show ) أول أشكال المسرح التجريبي ، وتختلف في طبيعتها عن حديث النفس / المونولوج

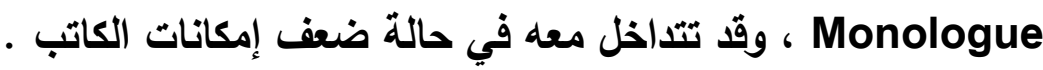
وترتبط المونودراما بنثأة المسرح عند اليونان ، وقد انتقلت من حالة السرد إلى التشخيص أو التمثيل ، الذي اصطبغ في بداياته بالصبغة الدينية ، قبل أن ينتقل ليعبر عن قضايا الحياة والأحياء.

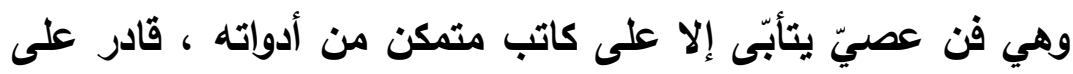
دمج الأصوات في صوت ، والثخوص في شخصية وإحدة ، والأنفس في

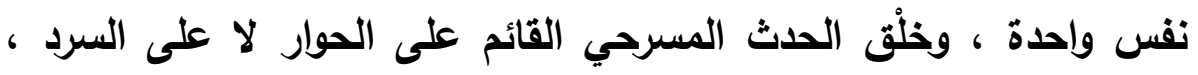
ومعالجة المعضلات الفنية التي تلاحق الفن مذ نثأته . وقا نثط فن المونودراما المسرحي في المملكة العربية السعودية نشاطًا

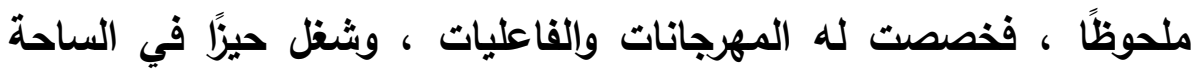

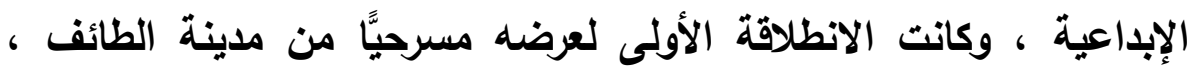

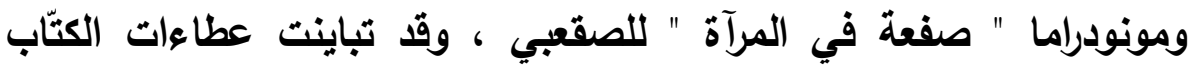

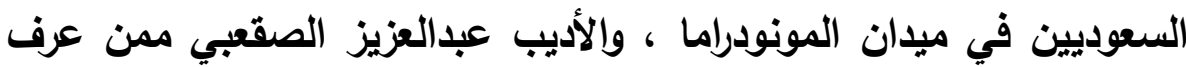
بإسهاماته المميزة في إزكاء مسيرة المسرح السعودي.

\section{7}

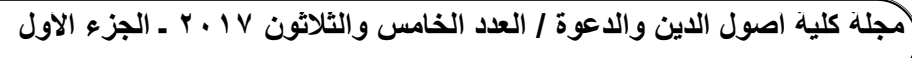


وترتبط رويته في أعماله المسرحية بقضايا المجتمعات الإنسانية ، وهموم وهواجس الإنسان المعاصر ، عالج فيها عددًا من هذه القضايا ، باسطًا عليها وشاحًا فنيَّا أضفى بعدًا جماليَّا ، إنْ في الطرح أو المعالجة أو البنية والعرض ، واستطاع أن يتعايش ، ويعالج في نصه المسرحي كثيرًا من إثكالات المونودراما ، مثل ( الحوار - الصراع - الصوت المسرحي المنفرد (وحدة الأداء ) - التلقي - التداخل مع المونولوج ) ). ويأتي هذا البحث ليكثف عن البنية والروئية ، ومصادرها في نص هل مونودراما مسرح الصقعبي ، وينية الفن وإشكالاته وطرائق المعالجة القنية لها ، وقسم بناء على تلك الأهداف إلى مقدمة وتوطئة ومهاد وثلاثة مباحث ، رصدت في التوطئة مسيرة المسرح السعودي لا سيما المونودراما ، وفي المهاد تناولت سيرة ومسيرة الأديب عبدالعزيز الصقعبي ، ودار المبحث الأول عن الروئية المسرحية ومصادرها في مونودراما الصقعبي ، وتناولت في المبحث الثاني بنية المونودراما الصقعبية ، واختص المبحث الثالث بطرح الإشكالات التي تلاحق فن المونودراما ، وطرائق الصقعبي في معالجتها ، ثم كاتت الخاتمة والفهارس الفنية . والحمد لله في الأولى والآخرة . 


\section{توطئة : هونودراما المسرح السعودي .. نشأة وتصور}

درج بعض من تناول رصد حركة المسرح في الخليج العربي - لا

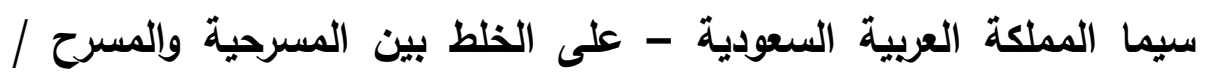
المخطوط والمنفذ ، فصدرث أحكامهم بتأخر ظهور هذا الفن في الساحة الأدبية السعودية ، وأحالوا تلك النسيئة إلى السمة المميزة للمجتمع السعودي

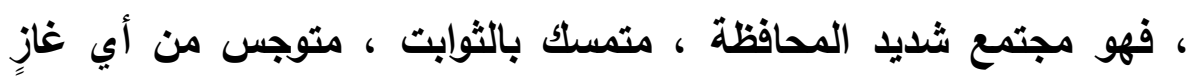
فكري أو فني ، يخشى منه المساس بتلك الثوابت أو الانو منها . ومن ثم راح بعضهم يشبه المجتمع السعودي بحال المجتمع الأورويي إبان عصر النهضة ، فكلاهما كان " ينظر إلى المسرح نظرة تدن نظرا إلى سطوة التقاليد ، فطوعوا المسرح نظرا إلى ظروف الحالة الوجداتية لكي يتساير معها ولا يتصادم ، فصدام فكرة المسرح مع فهم المجتمع وفكره يخلق نوعا من التراجع ، وهذا هو حال المجتمع السعودي " (1) . هذا التراجع في نشأة عروض الفن المسرحي يؤول إلى غريته القنية

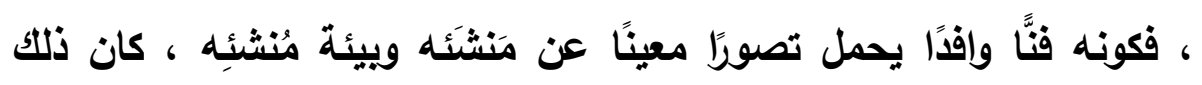
أدعى لعدم قبوله وتقبله وتذوقه ، لاى مجتمع رستخ في أذهان أفراده أنه نوع من الملهيات الماجنة ، التي لا يرجى درها .

(1 ) اللذة والكدر .. مقالات في المسرح واللدراما ، ص ع 1 ، ملحة عبدالله ، مؤسسـة

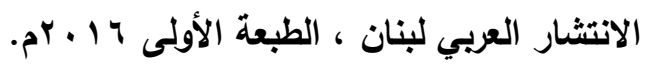

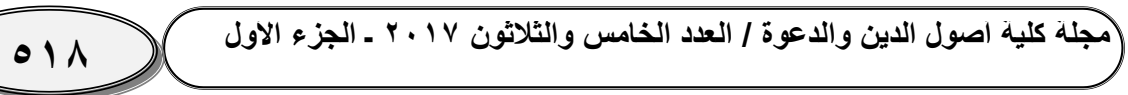


ولعل هذا هو السبب الذي أدي إلى وأد فكرة إنشاء أول مسرح

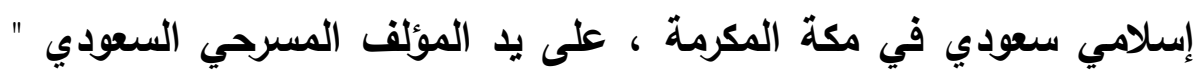

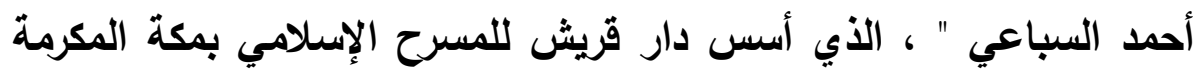

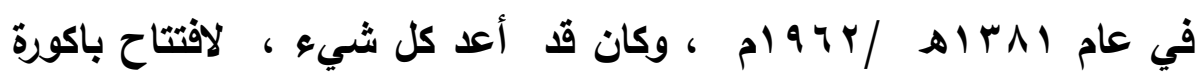

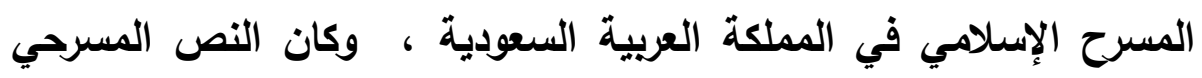

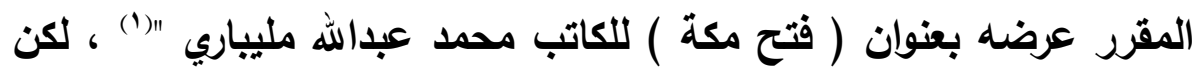

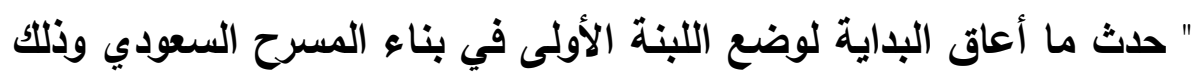

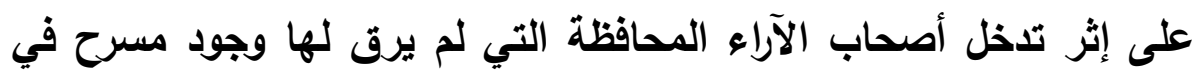

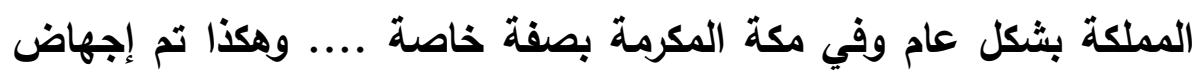

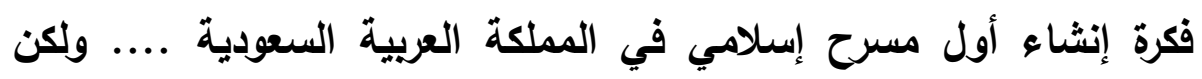

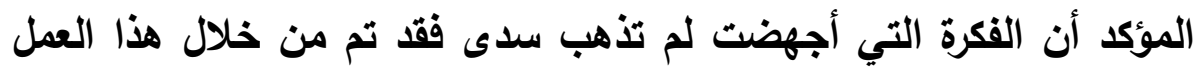

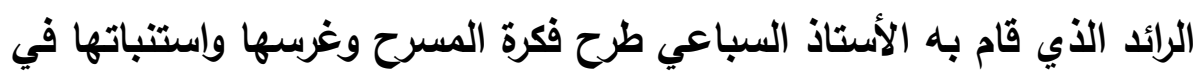

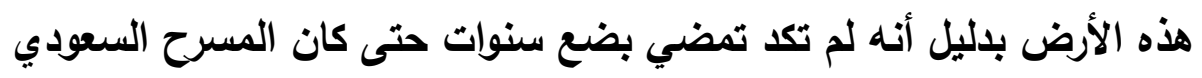

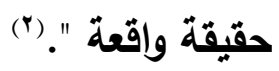

لهزا السبب كانت المملكة السعودية " من أحدث الدول العربية التي دخلها

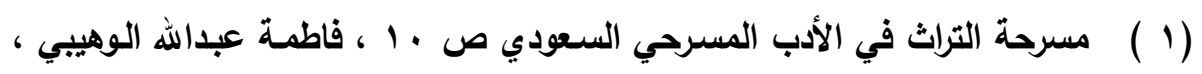

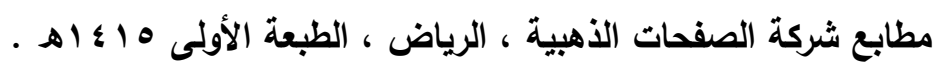

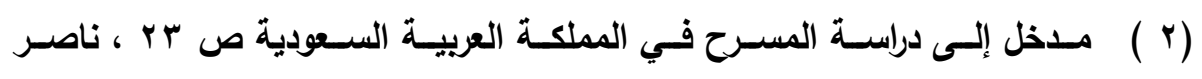

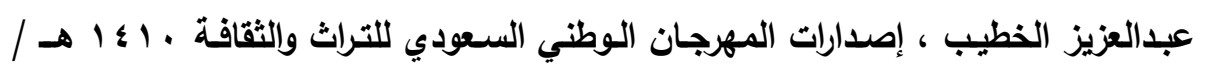

\section{9}

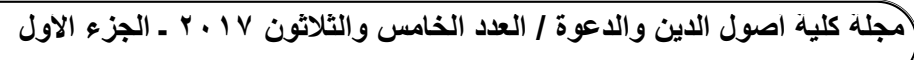


فن المسرح بشكله المتعارف عليه .. رغم كل المحاولات الأولى التي كانت تتم بثكل أو باجتهاد فردي " (1) ، وإن كان المسرح المدرسي في المملكة قد سبق فكرة تأسيس مسرح إسلامي أو أهلي ، " فأقدم مسرحية في تاريخ

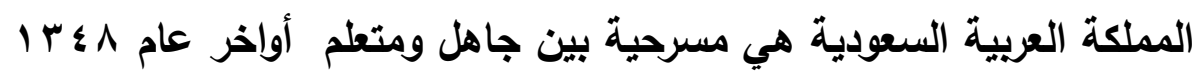

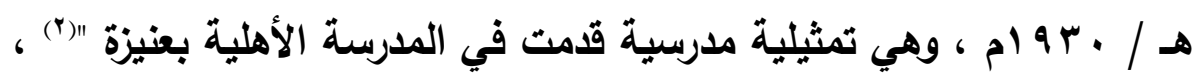
وإن رأى أحد الباحثين أن أقدم عرض مسرحي مدرسي في المملكة كان في

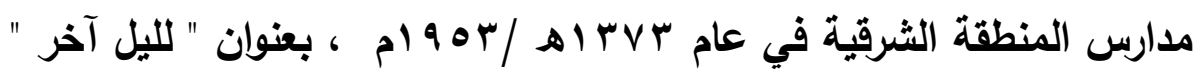
وهو صورة من صور الجهاد القلسطيني (ب)

وغير خاف أن هذه النسيئة لولادة هذا الفن في الساحة الأدبية السعودية إنما تتسحب على العرض المسرحي لا التأليف ، وإلا فإن الكتابة المسرحية في المملكة قا سبقت مرادها ، فكانت " أقدم تجرية في كتابة المسرحية الثعرية على مستوى المملكة العربية السعودية على يا حسين عبدالله سراج ، فقد أصدر مسرحية شعرية بعنوان ( الظالم نفسه ) عام

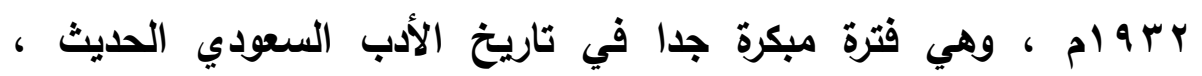

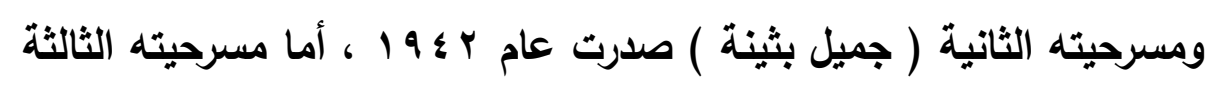

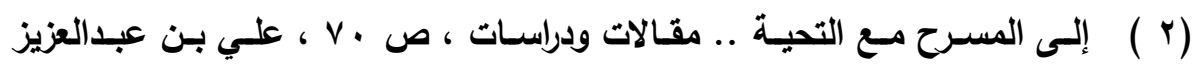

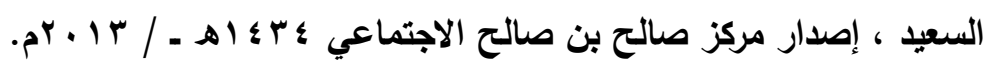

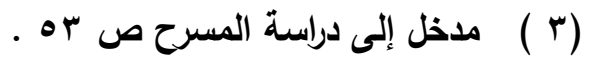

or. مجلة كلية اصول الدين والدعوة / العدد الخامس والثلاثتون VI ا r ـ الجزء الاول 
( غرام ولادة ) فقد أصدرتها دار المعارف بمصر عام 190 r ، بينما صدرت

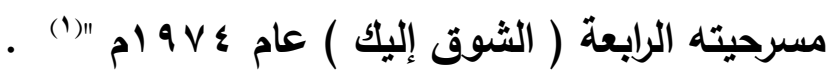
بيد أن المسرحية حياتها في المسرح لا بين الافاتر ، فما وضعت إلا لتعرض وتثخص ، إلا أن عدم عرضها " مسرحيا عن طريق التمثيل لا يلغي من وظيفة الدراما في النص المكتوب ، ولا يمنع اعتبارها أدبا مكتويا - يعتمد البناء الدرامي- من أداء وظيفتها الدرامية وأهدافها المسندة إليها كفعل خطط له العرض مسرحيا من قبل الكاتب نفسه ، ويستطيع القارئ تخيله "(() مهئ فخصائص المجتمع السعودي قد أوجلت نوعًا من المسرحية التي تقرأ فقط لاحتوائها أو نهوضها على عنصر نسائي ، وتلك عقبة كؤود تقف حائلًا بين النص وإمكانية تجسيده ، معنى ذلك " أن هناك كتابا سعوديين يكتبون المسرح من أجل المسرح أي أنهم يمارسون الفن للفن . ومن هنا فهم يكتبون المسرحية كما يجب أن تكون من حيث الأصول الفتية ... ومن أبرز مؤلفي هذا المسرح الدكتور عصام خوقير والشاعر حسين سراج " ("). ولعل كل ما سبق من نسيئة ظهور المسرح وحداثته ، وانزواء جل هداء النصوص المسرحية في رفوف المكتبات لتجريم عرضها ، وانشطار المسرح

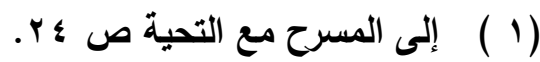

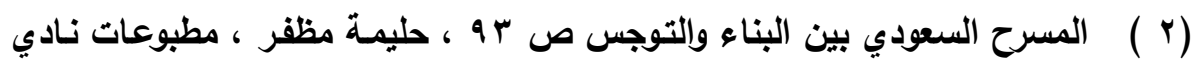

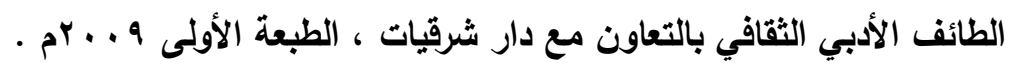

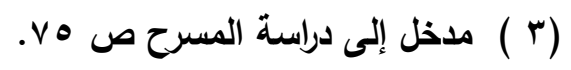

\section{OY 1} مجلة كلية اصول الدين والدعوة / العدد الخامس والثلاثتون V ا ب ـ الجزء الاول 
السعودي إلى عروض نسائية وعروض للرجال فقط ، كل ذلك يسم المسرح السعودي بسمات تفرقه عن غيره ، ف " الحركة المسرحية في السعودية لم تمر بمراحل الترجمة للمسرح ثم الاقتباس والإعداد ، أو تبدأ كما بدأ المسرح العربي بالاقتباس والإعداد والترجمة والتأليف ، ولكن المسرح السعودي بـأ بالتأليف مباشرة ، ولم يمارس الاقتباس ، ولم يمر بمرحلة الإعداد ، وهما مرحلتان تمهيديتان لمرحلة التأليف ، وتاليتان لمرحلة الترجمة ، ولذلك يجوز القول : إن المسرح السعودي بدأ في عجلة من أمره "(1) والمونودراما شكل من أشكال الفن المسرحي ، ذاع وانتشر تأليفًا وتمثيلًا في العالم العربي ، وهي " تركيبة درامية من المونولوج والمناجاة والجانبية على هيئة مسرحية قصيرة تتأسس بنيتها على صور متثظية لصراع نفسي يدور داخل شخصية واحدة متعددة الأصوات ، وهي أصوات درامية تستدعي مواقف ماضية من حياة الشخصية المونودرامية "(") .

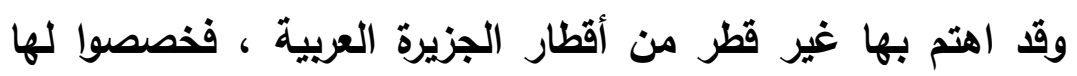
المهرجانات الدولية ، وكانت الانطلاقة الأولى مع مهرجان الفجيرة الدولي للمونودراما في عام ب ...rم ، ثم كان المهرجان الأول للمونودراما في

(1 ) نهار اليقظة في المسرحية العربية .. المسرح السعوي ص VV ، ، أبو الحسن سـلام

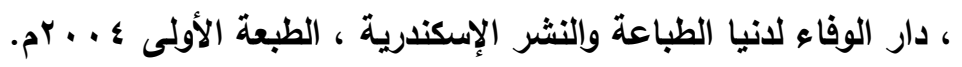

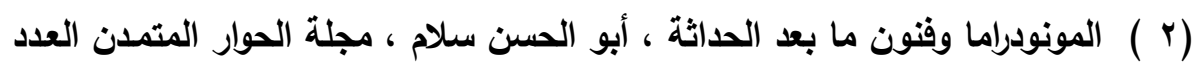

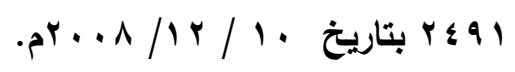

\section{OYY}

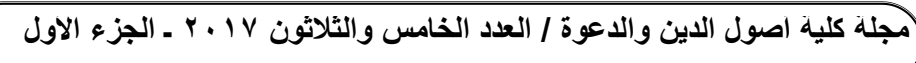


المملكة العربية السعودية في شهر صفر هب؛ اهـ ، نظمه فرع الجمعية العربية السعودية للثقافة والفنون في الطائف . لمعند ثم نظمت الجمعية في مقرها الرئيس في الرياض المهرجان الأول للمونودراما

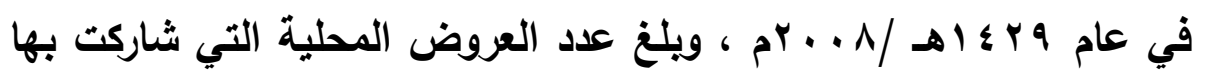

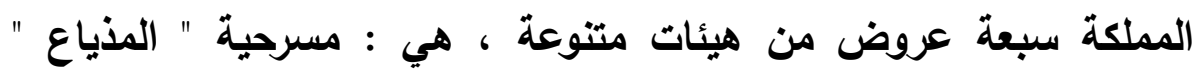

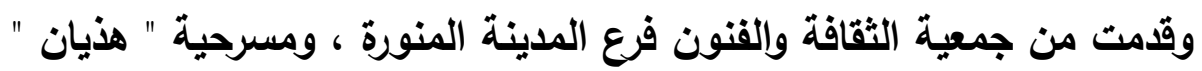

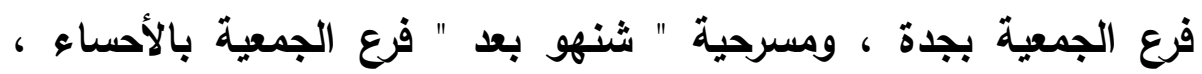

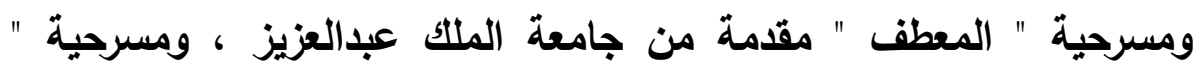

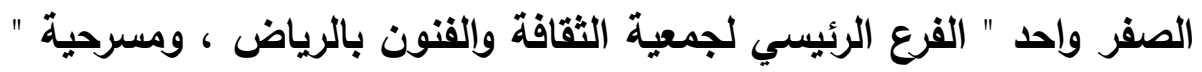

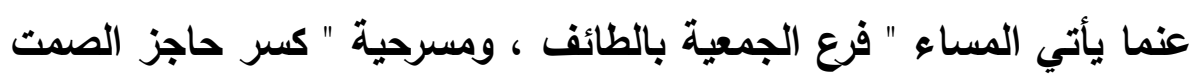

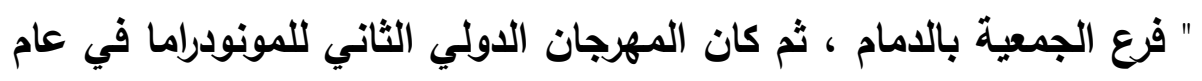

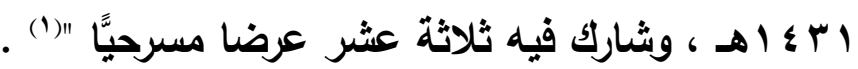

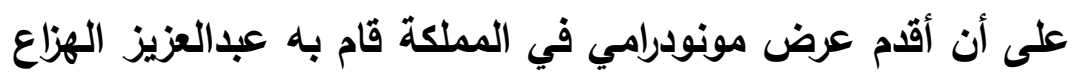

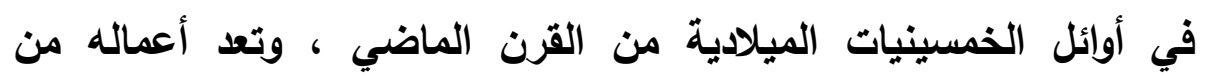

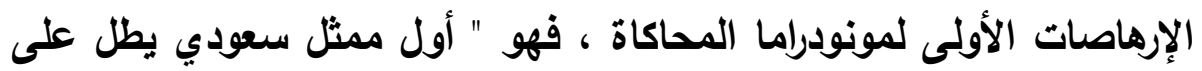

(1 ) ينظر : الجمعية العربية السعودية للثقافة والفنون .. وأربعون عامـا من المسرح

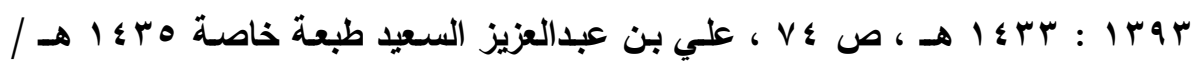

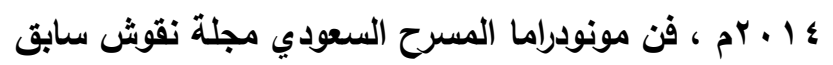

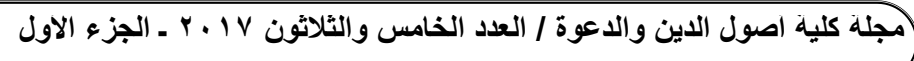




\section{(1) " الخشبة في حوار درامي يقوم به شخص واحد}

وحلقت مونودراما المسرح السعودي خارج حدود المملكة ، وكان أول مشاركة لها في مهرجان المسرح العربي المتنقل بالمغرب ، ونظمته جامعة الاول العربية في عام ع 9 ام ، وعرضت فيه مسرحية " صفعة في المرأة " لعبدالعزيز الصقعبي ، ثم عرضت المسرحية مرة أخرى في الأسبوع الثقافي السعودي في دولة الجزائر عام ع . ع ا هـ (؟) ، كما شاركت الجمعية العربية السعودية للثقافة والقنون بعرضين مسرحيين في مهرجان اللاذقية لمسرح

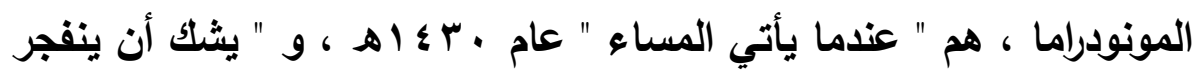

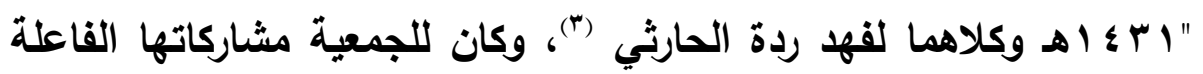
في مهرجان المسرح العربي بالقاهرة منذ عام \ ـ . ب ، وشاركت الجمعية في

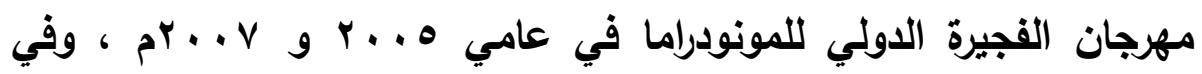
مهرجان فاس الدولي للمسرح الاحترافي عام \& \& ع ام (\&). ولا شك في أن تلك النشاطات المحلية والمشاركات الدولية وعطاءات

(1 ) المسرح السعودي .. دراسة نقدية ص ^^ ، ، نذير العظمة ، الناشر : النادي الأدبي

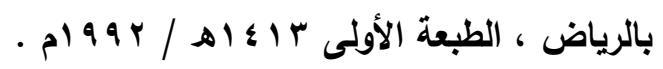

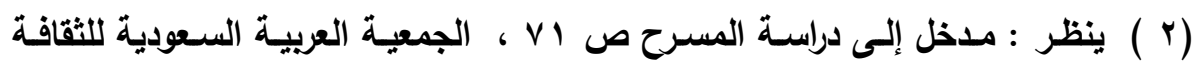
والقنون ص ا 1 ، ، سابق.

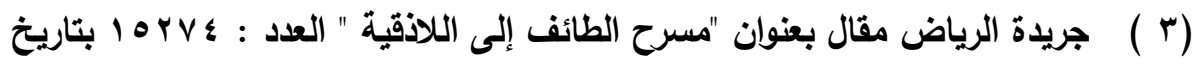

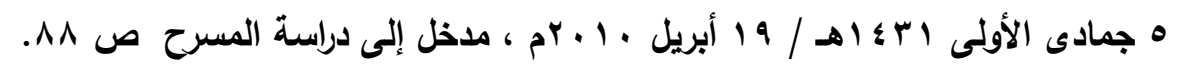

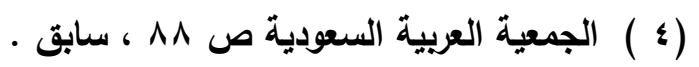

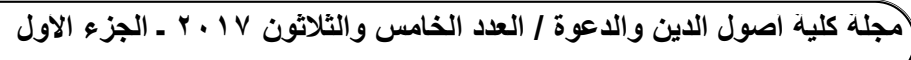


المباعين المتلاحقة ، تلال على اهتمام بالغ بهذا الفن ، الذي بدأ يفرض

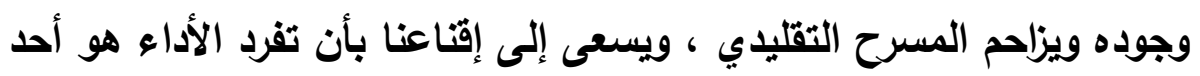

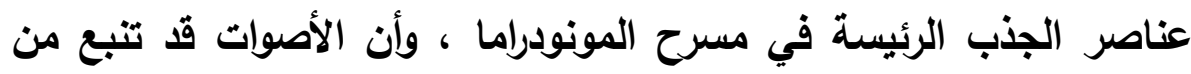

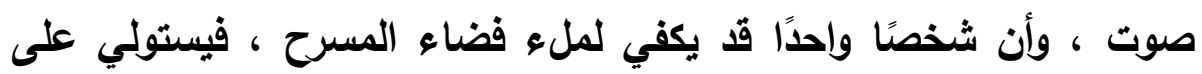

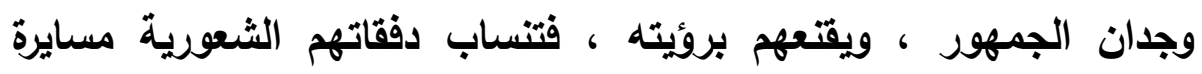

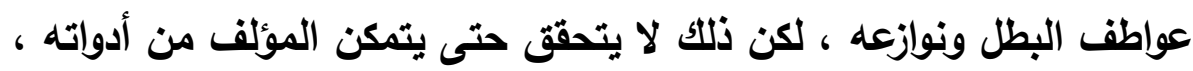

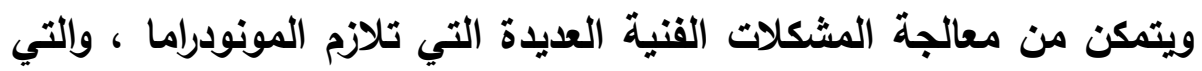
سنعرض لها في الجانب التطبيقي من هذا البحث . 


\section{ald}

\section{عبد العزيز الصقعبي .. سسيرة وهسيرة}

ولا الأديب السعودي المعاصر عبدالعزيز بن صالح الصقعبي في مدينة الطائف

المؤهلات العلمية :

حصل على ماجستير المكتبات وتكنولوجيا المعلومات من الولايات المتحدة الأمريكية ، ويكالوريوس اللغة عربية من كلية الآداب جامعة الملك سعود. المناصب العلمية والإدارية :

- عمل مديرًا عامًَا للإيداع والتسجيل ، ومشرفًا على العلاقات والثئون الثقافية في مكتبة الملك فهر الوطنية. - كلف برئاسة تحرير أخبار المكتبة ، ونشرة المستخلصات الصادرة عن مكتبة الملك فهر الوطنية، وعمل مستشارًا في الفهرس العربي الموحد . - محرر ثقافي في جريدة الرياض، يكتب زاوية أسبوعية بعنوان ضوء . - مدير تحرير المجلة العربية. - عضو مجلس إدارة جمعية المكتبات والمعلومات السعودية للاورة الأولى . - عضو نادي الطائف الأدبي وجمعية الثقافة والقنون بالطائف ونادي القصة السعودي.

- مثّل المملكة في عدد من الملتقيات والمؤتمرات الثقافية والعلمية . - شارك في عدد من اللقاءات والأمسيات القصصية، وقدم عدة شهادات

\section{ory}

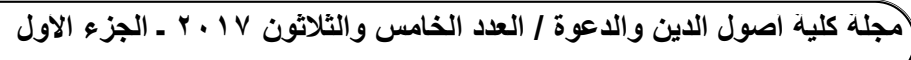


مؤلفاته الإبداعية : يكتب القصة القصيرة والرواية والمسرحية بنمطيها والمقالة والسيناريو

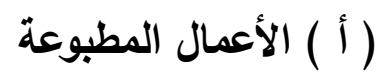

ا - لا ليلك ليلي ولا أنت أنا - مجموعة قصص - نادي الطائف الأدبي . $1 \varepsilon \cdot \mu$ r - صفعة في المرآة - مسرحية مونودراما - طبعتان رعاية الشباب

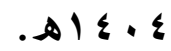
r - رائحة الفحم - رواية- الرياض 1 ، • ع اهـ. ع - الحكواتي يفقد صوته - قصص قصيرة- جمعية الثقافة والفنون

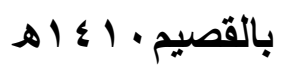

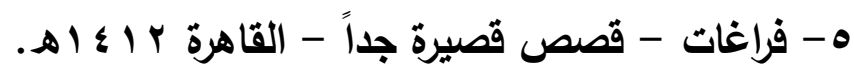
צ- يوقد الليل أصواتهم ويملأ أسفارهم بالتعب - قصص قصيرة- نادي

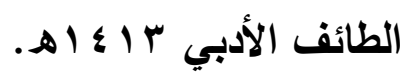

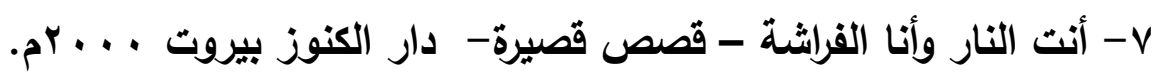
^- أحاديث مسائية - قصص قصيرة - المركز الثقافي العربي V . . r م . 9- حالة كذب المركز الثقافي العربيء · . •rم.

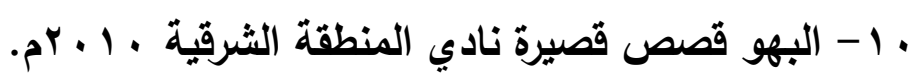
1 - صفعة في المرآة ومسرحيات أخرى ، وزارة الثقافة والإعلام ، و دار

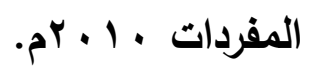

\section{๑rV}

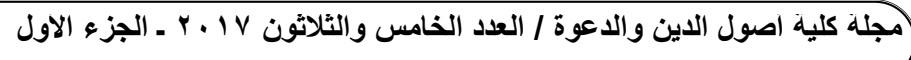


r ا - طائف الأنس - رواية- دار بيسان بيروت 11 ـ بrم.

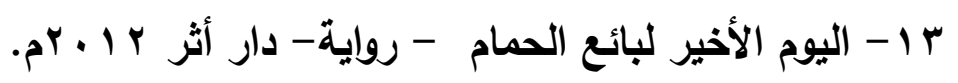

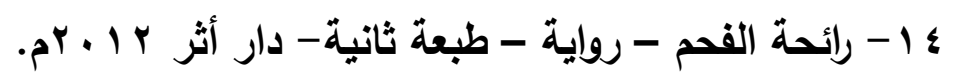

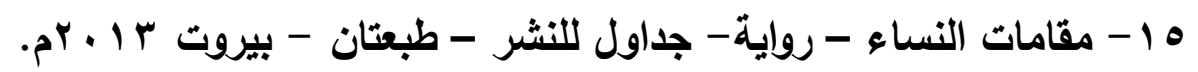
17 - حارس النهر القديم - قصص - منشورات ضفاف /الاختلاف $\cdot p^{r} \cdot 10$

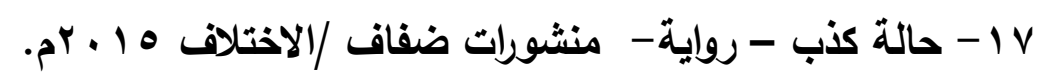

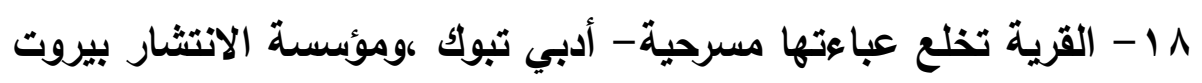
$\cdot p^{r} \cdot 17$

9 ا - قصص قصيرة مختارات مما نشر في المجلة العربية إعداد 17 ـ ب م. ( ب ) الأعمال المسرحية المنفذة: - صفعة في المرآة - مونودراما- : الطائف ب ، ـ اهـ ، والأسبوع الثقافي السعودي بالجزائر، مهرجان المسرح العربي المتتقل بالمغرب: رعاية الشباب

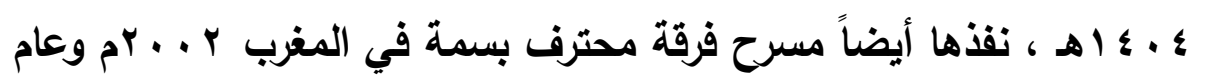
$\cdot g r \cdot 1 r$ r- واحد صفر - مونودراما - الرياض ه ه. . أه أخرجها تلفزيونياً : سعد

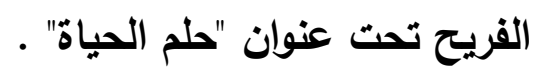

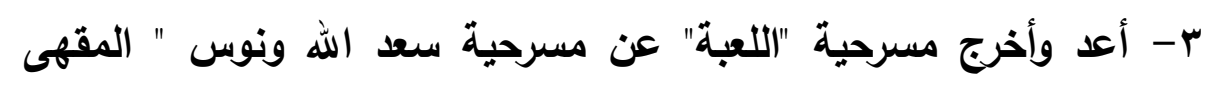

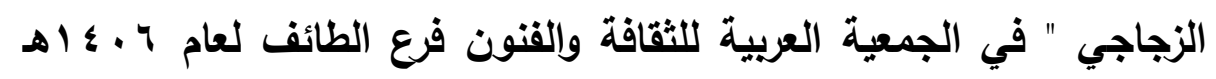


ع - واحد اثنان ثثلاثة مسرحية من عدة مشاهد مثلت المملكة في مهرجان

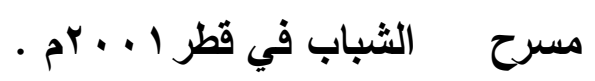

ه- مسرحية " ولادة متعسرة" مونودراما مركز ابن صالح الثقافي عنيزة

(1).

وتعد مونودراما " صفعة في المرآة " أول مونودراما تعرض على

خثبة المسرح في المملكة العربية السعودية ، ومن يومها بات عبدالعزيز الصقعبي يمثل حضورًا بارزًا في التأليف والإخراج لمسرح المونودراما ، فلم تكن " صفعة في المرآة " مغامرة أو نزوة إبداعية ، بل مثلت نقطة ارتكاز (ץ). لانطلاق الصقعبي في فن المونودراما.

(1 ) مـن واقع سجلات الأديب ، وينظر : المسرح في المملكـة العربيـة السعودية ..

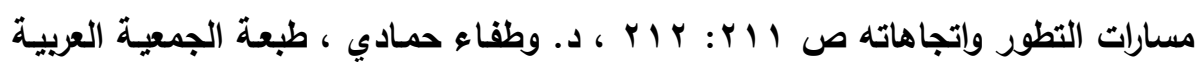

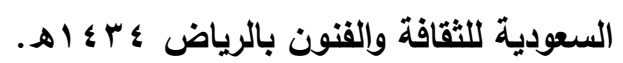

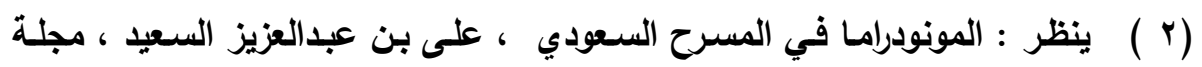

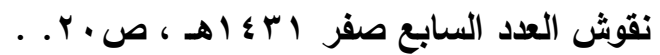

\section{or 9}

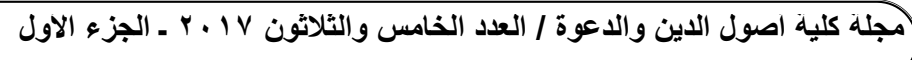




\section{الاببمث الأولى}

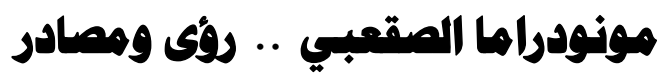

يشكل الفن المسرحي أحد أبرز عناصر الثقافة في المجتمعات ، وأحد أهم نوافذ الأدب ومنابره ، و " الأثكال المسرحية هي في حقيقة الأمر أنشطة ثقافية لا تتفصل عن وجدان المجتمع وحركته التاريخية - أي أنها ليست

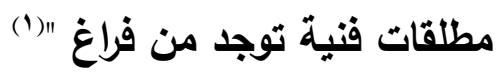

والمونودراما وإن كاتت أحد أثكال الفن المسرحي إلا أنها غير قادرة

إلى النفاذ في عمق المشهر المجتمعي ، ونقد أوضاعه أونقضها ، وطريقتها في التصادم مع السلبيات ملتوية تقتقر إلى المباشرة ، تجنح إلى استخدام الأسلوب الساخر ، فطبيعتها الفردية / الانعزلية الاختزالية تحول دون إمكانية الطرح الشامل والمعالجة الكاملة لقضايا المجتمع ، فتكتفي باللمحة والإثارة ، فبطلها هائم في أحلامه سابح غارق في اجترار ماضيه غير قادر على معايشة آنيه . مانمان

فددود المونودراما الفنية تكاد تقتصر على تعرية عوالم المؤدي الاخلية والخارجية المحدودة ، ومن ثم فالواقعية الفردية ( الرومانسية ) تكاد تكون أحد أهم مصادر هذا الفن ، وهذا يؤول إلى أن الأركان القنية للمونودراما المسرحية قد اكتملت في رحاب الحركة الرومانسية التي نادت

(1 ) التيارات المسرحية المعاصرة ص ع ؟ 1 ، نهاد صليحة ، الهيئة المصرية العامـة

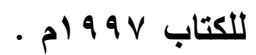

○.

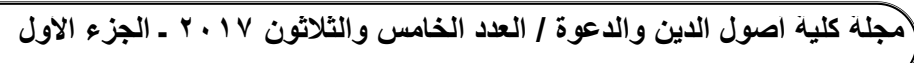


بتقديس النزعة الفردية.

يعرض الأديب عبدالززيز الصقعبي في مونودراما " صفعة في المرآة " قضية اجتماعية بارزة ، إذ يعاني البطل / الموظف من تسلط وتجبر رئيسه

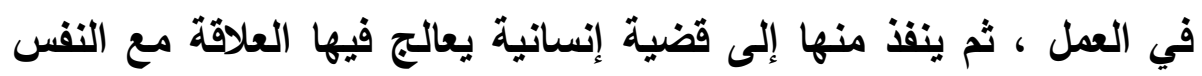

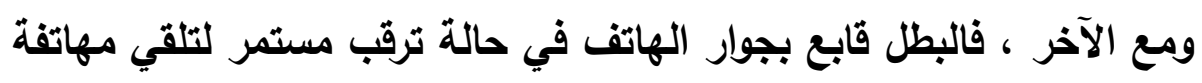

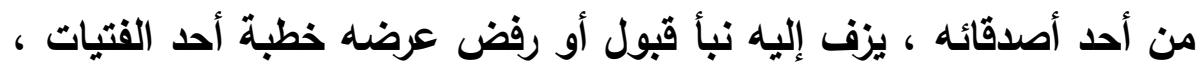

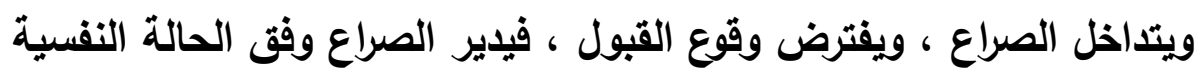

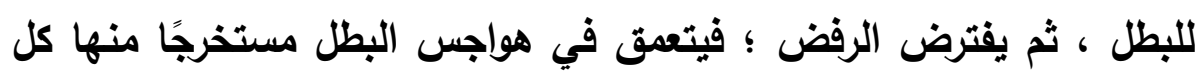

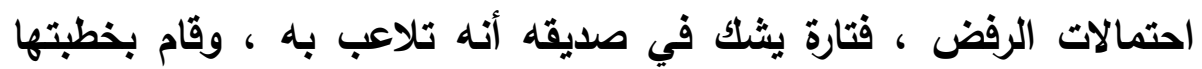

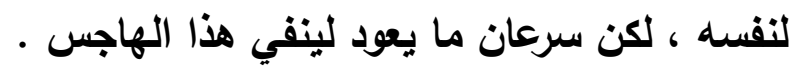

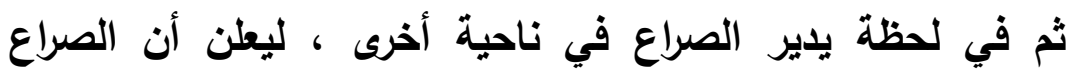

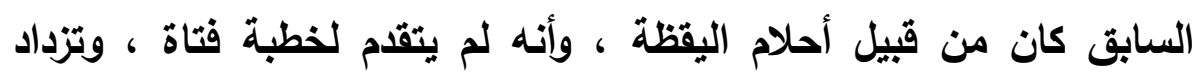

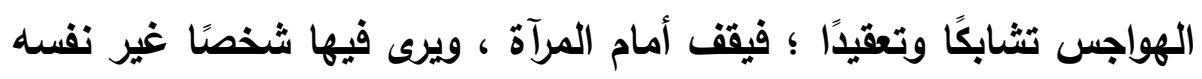

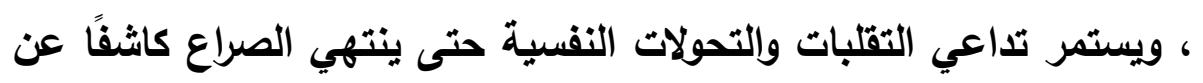

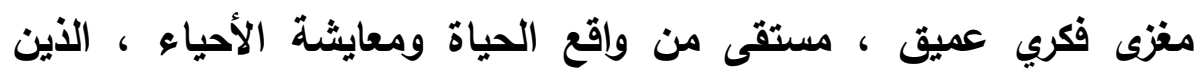

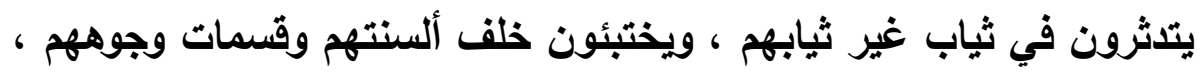

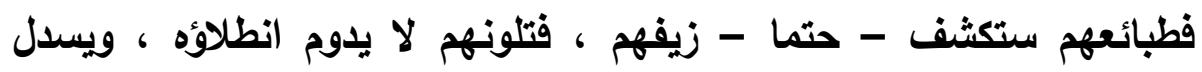

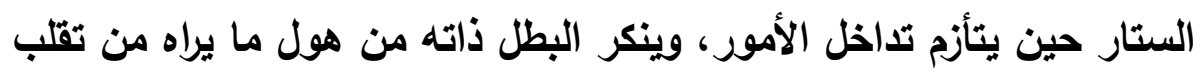

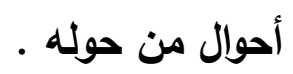

ويرى الأستاذ ناصر الخطيب أن الروئية الفكرية في هذه المونودراما 
تتمثل في أن " الحقيقة المطلة شيء مستحيل ، وإن أقصى ما يمكن أن

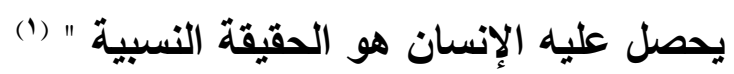
والحق أن في قوله جناية على المغزى الفكري للمسرحية ، فلا يمكنتا

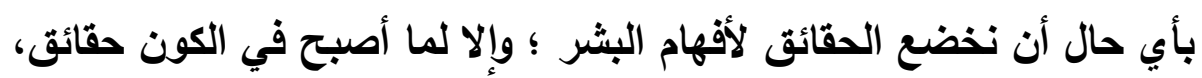

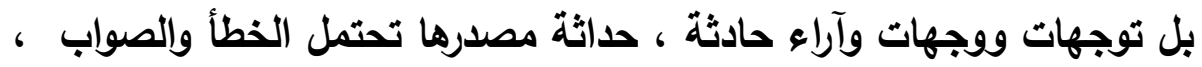

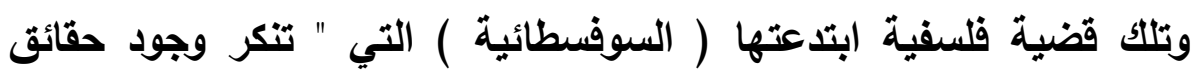

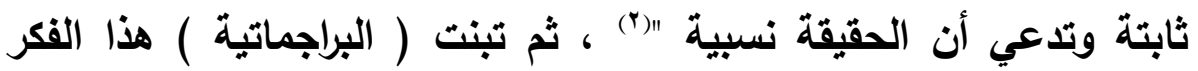

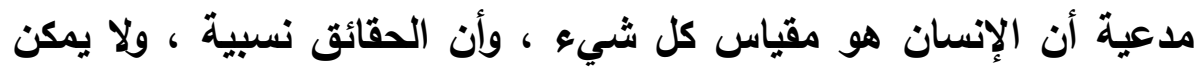
الوصول إلى حقيقة مطلقة . ويعيدًا عن هذا الجدال الفلسفي ، فليس هذا هو جوهر الروئية الفكرة، فالصقعبي قد اتجه بنصه إلى التراجيديا فصبه في قالب مأساوي ، مستعرضًا

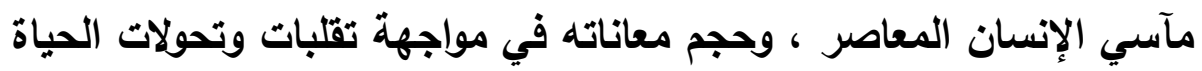

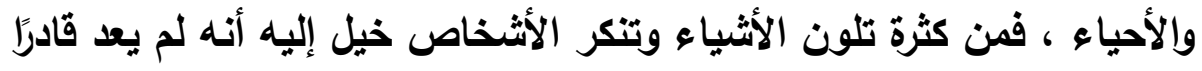

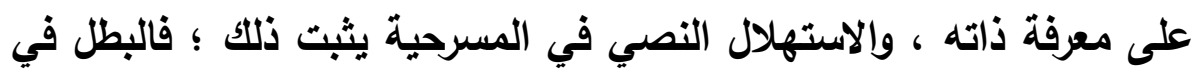

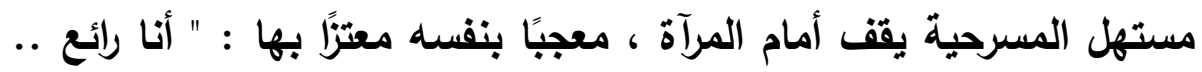

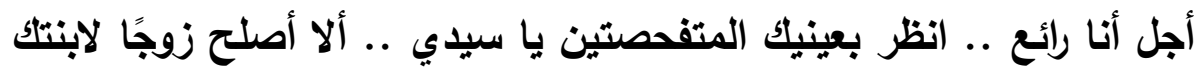

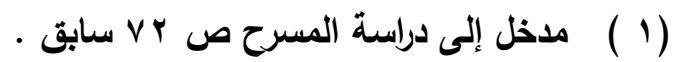

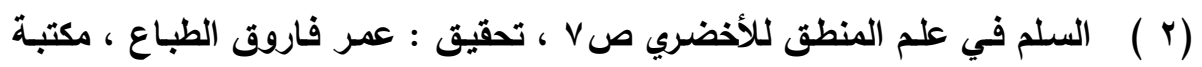
المعارف ، بيروت . - الميلمي 
؟ .ألا أصلح ؟ أتثكك بهذا .. ومن بشك ؟ .. أنا أشك .. لا .. أنا متأكد .. ومن

غيري يصلح زوجا لابنتك ؟! (1) فالثبات والثقة بالنفس التي تمتع بها في بداية الصراع ؛ تجعلنا نجزم بأن

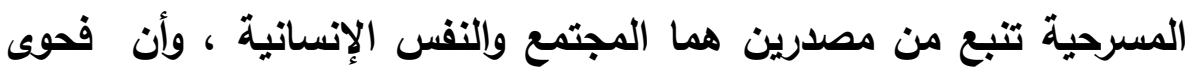

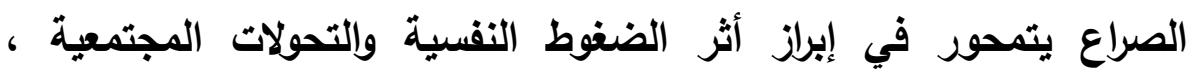
وتقلبات العلاقات الإنسانية على حياة وسلوك الأفراد ، كما أن الانعكاس الصوري في المرآة يجعل الصورة تدور " مع أصلها وجودا وعدما ، فإن وجدت كان الأصل موجودا ، وإن انعدمت أو غابت كان الأصل منعدما أو غائبا ، وهذا يعني أن المرآة ليست فقط الصورة ، إنما هي تقدم للأصل ، أو الو الوان

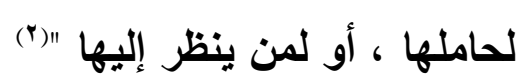

من هنا فالقيمة الحقيقية للمسرحية " لا تتجلى إلا بالربط الواعي بينها وبين المضمون الأي تثتمل عليه بحيث يكثف لنا هذا الربط عن تعانق تام بين الثكل والمضمون ، يفضي كل منهما إلى الآخر ، حتى يصبح من المستحيل الفصل بينهما أو تصور إمكانية قيام أي منهما في حالة تخلف عن

(1 ) صـفة فـي المـرآة ومسـرحيات أخـرى صـ 1 ، وزارة الثقافـة والإعـلام ، المملكـة

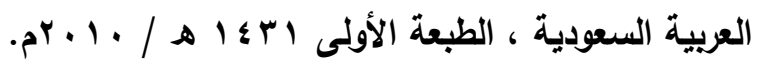

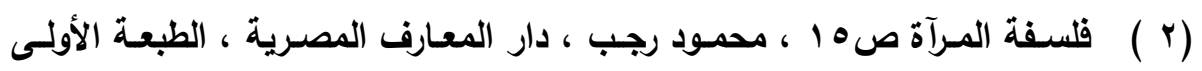


وقد لجأ الصقعبي في هذا النص إلى القتاع / المرآة التي تمثل الانعكاس ، وهي تقتية " رمزية قديمة تضرب بجذورها في الميراث الإنساني الأسطوري والقلكلوري والإبداعي على السواء ، وهو ميراث ظل مصدر إلهام - في بعض جوانبه لإبداعات حديثة "(آ) ، فالمرآة أنجع الأدوات والتقتيات الإبداعية للولوج إلى الأت ؛ كونها كفيلة بكثف غير المرئي ، فما من " وسيلة لمعرفة الأت غير تثلك المواجهة عبر المرآة ، حيث يرى الإنسان نفسه ، وهو يرى نفسه ، أو حيث ينظر إلى نفسه وهو ينظر إلى نفسه "(")

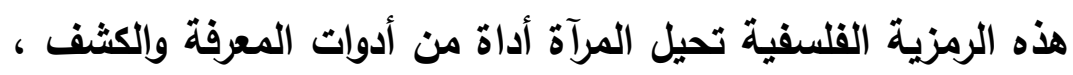

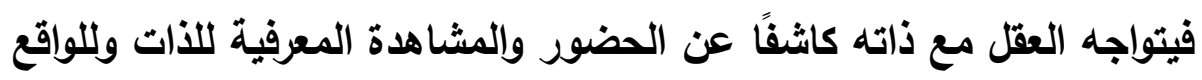
المحيط ، ومن ثم كانت المرآة وسيلة مثلى لاستظهار ما يعانيه البطل من

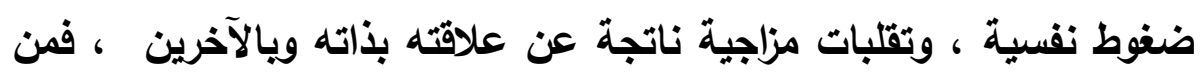
فرط فقده الثقة بنفسه ويغيره يلجأ إلى تعنيف ذاته ومحاسبتها . ومن ثم كان لابد من استحضار تلك الأات ، فكانت المرآة / الرمز وسيلة لاستحضار المؤسس لهذا الصراع وتلك المعاناة ، فهي تجلي الزيف

(1 ) الكتابة خارج الأقواس .. دراسات في الثعر والقصة ، ص ب ب إسعيد السريحي،

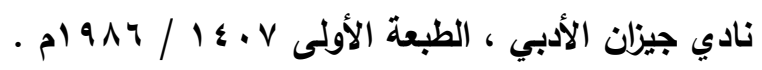

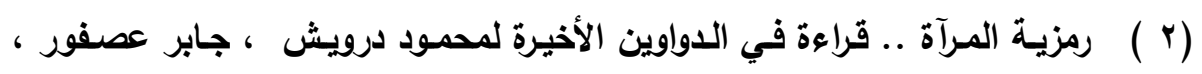

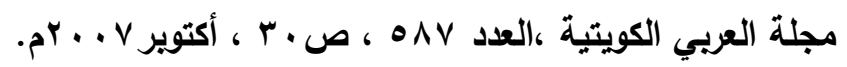

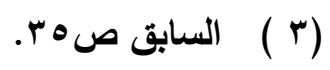

Or مجلة كلية اصول الدين والدعوة / العدد الخامس والثلاثتون V ا ـ ـ الجزء الاول 
من غير مجاملة ، فكل مبالغة في القول والحركة ، إنما هي نابية عن التمثيل ، وما هذه الغاية منذ البدء إلى اليوم إلا أثبه بإقامة المرآة أمام

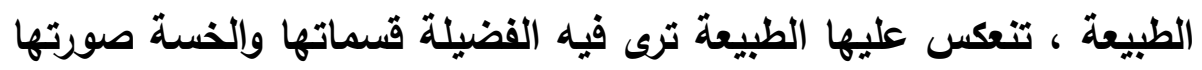

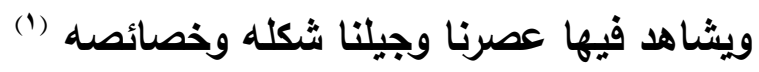

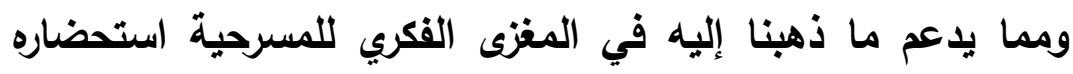
لوحة الموناليزا ، واستخدامها قناعًا يعبر به عن غموض وتقلبات من حوله:

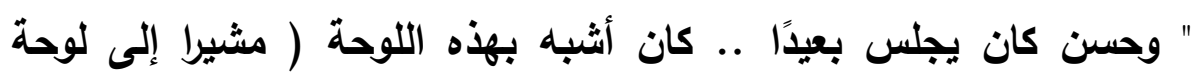

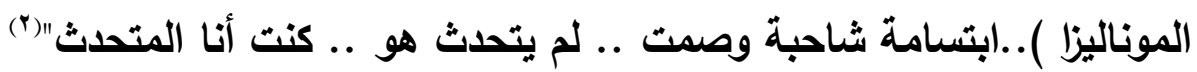

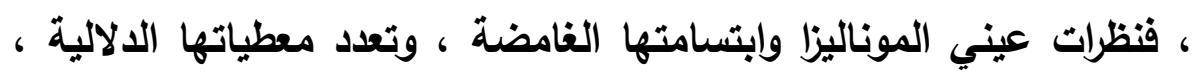

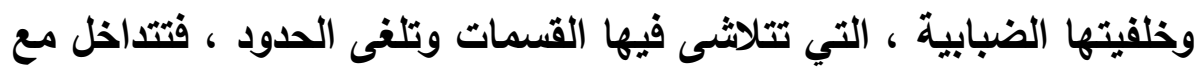

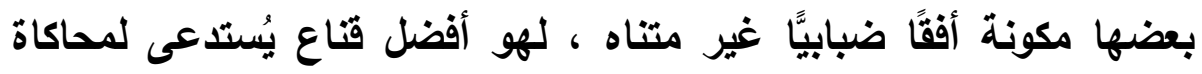
تحولات البشر وتقلباتهم. كما كان لحضور الصورة في أثناء العرض فاعلية خاصة ، فهو من

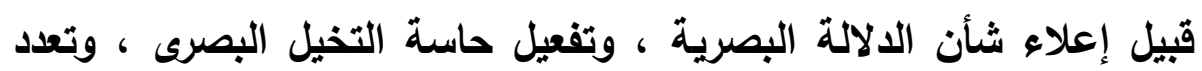

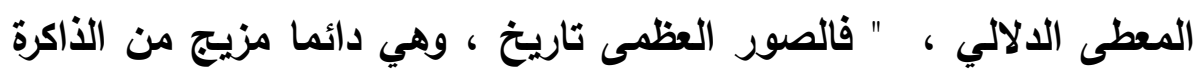

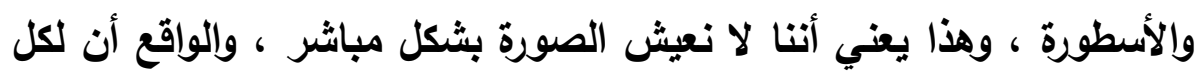

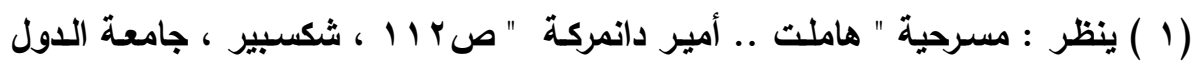

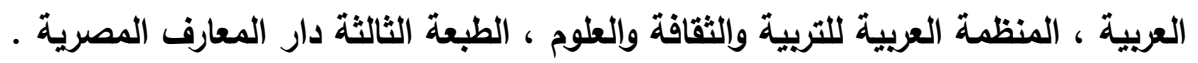

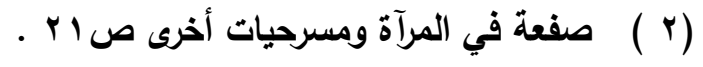
oro

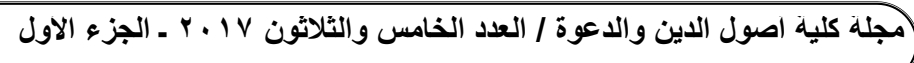


صورة عمق حلمي بعيد الغور ، يضيف إليه التاريخ الشخصي لونا خاصا"(1).

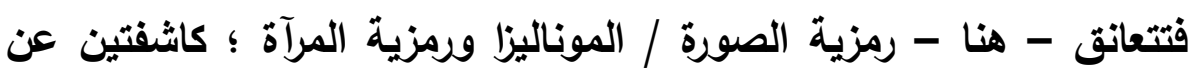
حالين متناقضين : " الابتسامة لا تقنعني قد تكون ستارًا .. بالفعل هي أشبه بالستار .. مثلها مثل ابتسامة المدير .. سأرفض بعد الآن أي ابتسامة..

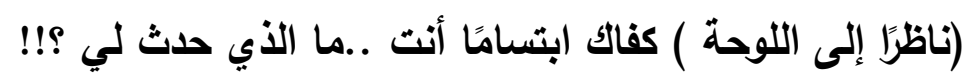

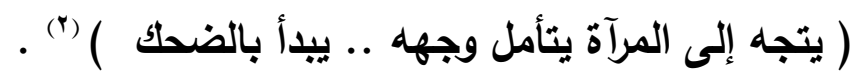
كما أن التتلاعب المتعمد بضمير المتكلم - " الأي ليس سوى ضمير المخاطب ، في فعل التجريد بمعناه البلاغي - دال على انشطار الوعي ، وانقسام الأت ما بين مبدأ الواقع ومبدأ الرغبة : الأول يشدها إلى قبول ما بادي هو واقع ، بينما يجذبها الثاني إلى النقيض"(") ، فتتجلى المفارقات كاشفة عن حجم المعاناة ، وحالات النزاع النفسي التي يكابدها هذا الإنسان ، وتحتاج معجمًا نفسيَّا يعبر بعمق عن ذلك الصراع النفسي ، فالصفعة التي تلقاها البطل في المرآة "هي صفعة الحقيقة التي تنكشف لنا حينما نبدو في حالة عجز تام عن الانعتاق من أسر الأت في علاقتنا مع الآخرين ، على نحو نصبح فيه جزرا متناثرة في محيط المجتمع .. جزرا لا تصل بينها

(1 ) جماليات المكان ص VV ، غاستون باشـلار ، ترجمـة : غالب هلسـا ، المؤسسـة

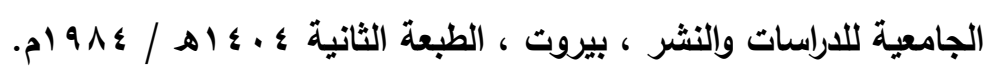

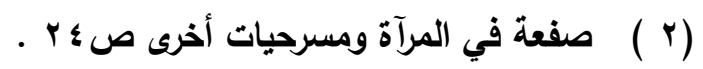

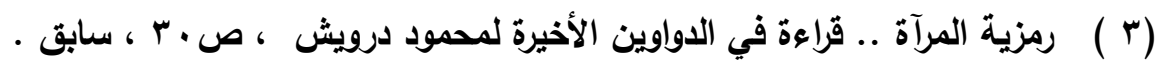
ory

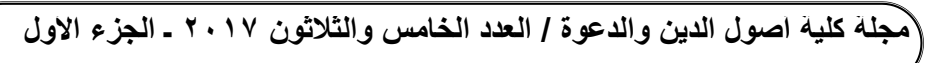


شواطئ ، ولا تربط بينها جسور .. حقيقة أن الإنسان يحيا وحده مع الآخرين

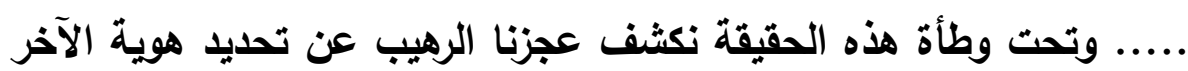

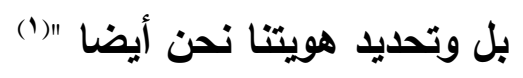

ومما يدعم - أيضًا - ما ذهبت إليه في المغزى الفكري أن بؤرة

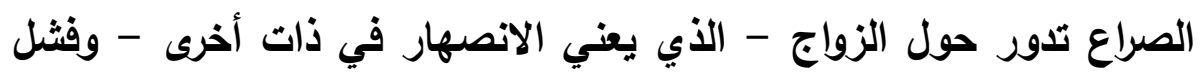

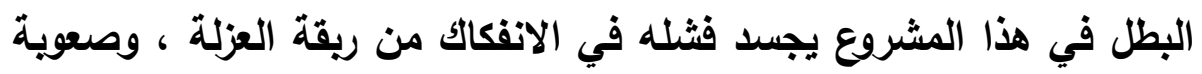
الامتزاج والتآلف مع من حوله ، وأن علاقاته بمن حوله هشة فئل تحكمها

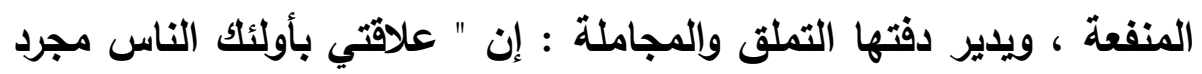

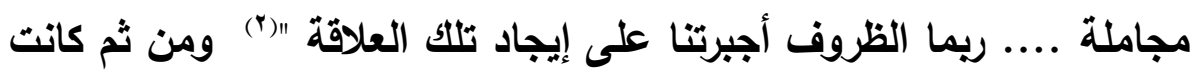

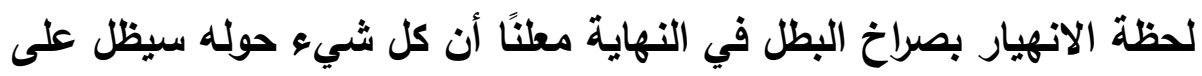

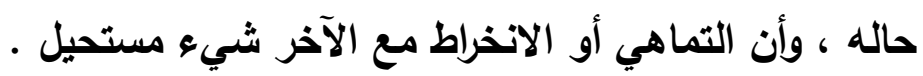

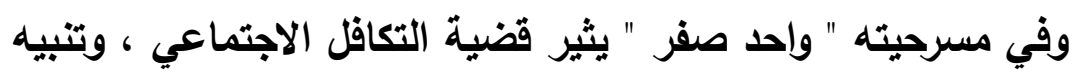

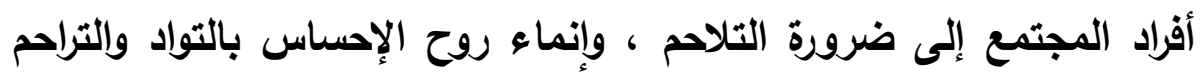

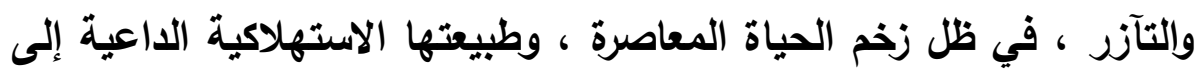
الاستقلالية أو الانعزالية ، أفصح الصقعبي عن مراده في استهلاله للمشهر

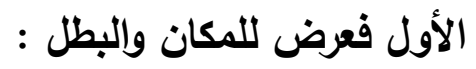
" المنظر : حي شعبي.. بيوت طينية بعضها بجانب بعض ، شاول ؛ شارع صغير ..

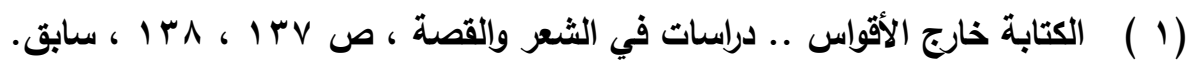

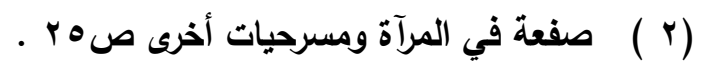
orv مجلة كلية اصول الاين والدعوة / العدد الخامس والتلاثتون IV ـ ـ ـ الجزء الاول 
من الجانب الأيمن ياخل رجل يدفع عربة صغيرة .. يبدو عليه العوز .. بائع كماليات .. يدعى ( عبيد ) " (1) فتأطيره للفراغ أو الفضاء المسرحي ، وتحديده للبعد الخارجي للشخصية ساعد منذ الوهلة الأولى في إبراز البعد الرئيس في العرض المسرحي وينية المشهر ، كما أسهمت تلك الالالات المكانية لمسرح الصراع ، ورسم البعد الخارجي للبطل في إدراك الفعل الدرامي ، واتساع أفق المشاهدة ، ورسم

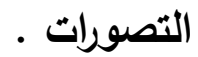
ثم أشار إثارة صريحة إلى مغزى المسرحية ، ملَّا في إبرازه مع أول دورة :للصراع " عبيد : لا أحد .. لا أحد .. أين أنتم ؟؟ .. أنسيتموني ! .. أنا عبيد ..... أين أنتم ؟؟ .. وحيد أنا .. هل غادرتم الحي ؟ .. ريما

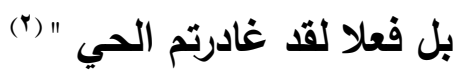
كما كان لصرخات البطل وصيحاته ، وكثرة تساويلاته أثرها في الكثف عن نفس متخمة بالهموم والآلام ، المنبعثة من فقده إحساس الناس به وتجاهلهم له ، مع سعيه الدؤوب في خدمتهم وتلبية حاجياتهم • فالصقعبي يلح في إبراز عزلة الإنسان المعاصر ، وشعوره الائم

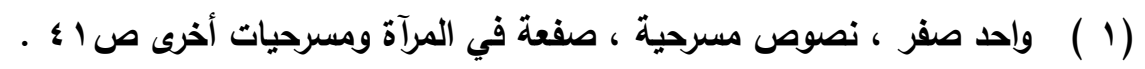

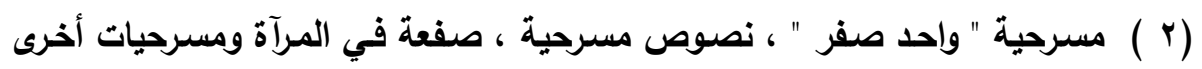

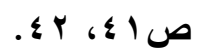

\section{OrA} مجلة كلية اصول الدين والدعوة / العدد الخامس والثلاثثون V ا ب ـ الجزء الاول 
بالاغتراب ، وعجزه عن تحقيق الاندماج والانصهار في بوتقة محيطه المجتمعي ، هذا ما سعى - أيضًا - لإثباته في مستهل مسرحيته " ولادة

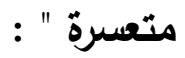

جبران : - بصوت مرتفع - أين أنت يا .... يا ... أين أنت يا ... يا ...لا حول ولا قوة إلا بالله " متجها إلى الجمهور " .. من منكم رآه .. يا ..... يا من؟ ... ما الأي أصابني .. إنه الوهم .. أجل الوهم .. إنتي مصاب

بالوهم

" محدثا الجمهور " وأنتم كذلك (1) ".

فالبطل فاقد الثقة في نفسه ومن حوله ، يبحث عن المجهول ، ويرى أن الناس جميعهم مسكونون بهذا المرض العضال ، الأي يعد من الاضطرابات الإدراكية ، التي تصيب الأصحاء ، فتكبلهم بالأغلال ، وتعتقلهم خلف جدران الهواجس النفسية ، تفقدهم لذة الحياة ، وتورثهم سوء الظن والفهم ، حال اغترابهم أو هروبهم من واقع الأت وواقع الحياة ، إلى المجهول أو اللاوعي أو العقل الباطن الذي يكثف " أسرارا خفية في حياة الإنسان يتطلب إدراكها الوصول إلى أفضل صيغ التأمل ، وذلك استعدادا للغوص في ميادين المجهول التي لا يمكن إدراكها بالعقل وحده "(؟)

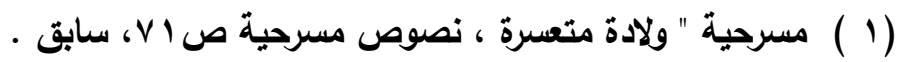

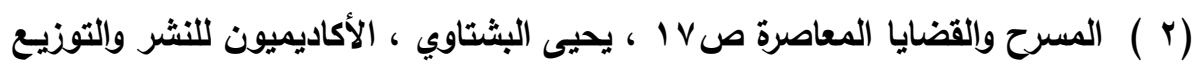

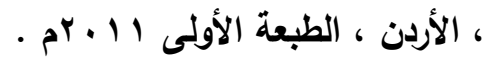


والوهم لون من ألوان الأدواء السيكولوجية / الروحية ، وشكل من

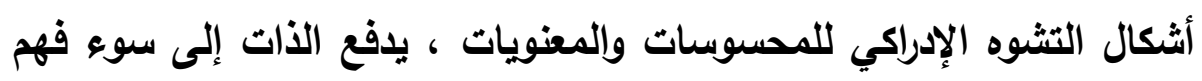

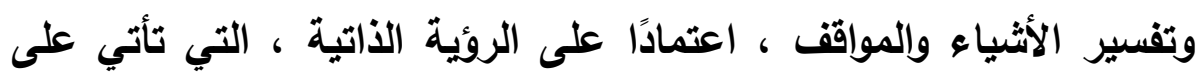

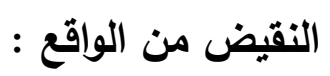
جبران : " بصوت مرتفع " .. يا أهل الحي .. لماذا هجرتموه .. كيفكم ..

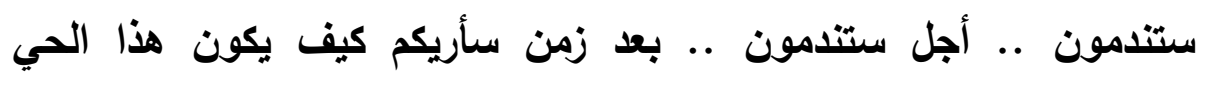

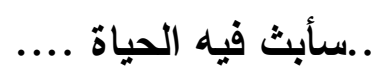

سأعيد بناءه (بـ نـ قـ وو ..... ) " يتوقف " ..... ما الذي أصابني حتمًا سيجتاحني الوهم مرة أخرى .. لقد جئت هنا لأعيش بعيدًا عن الوهم" (1).

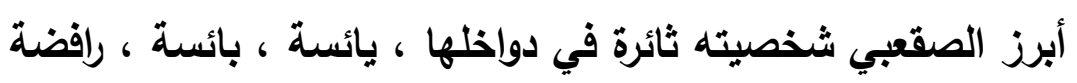

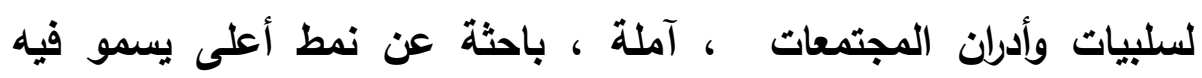

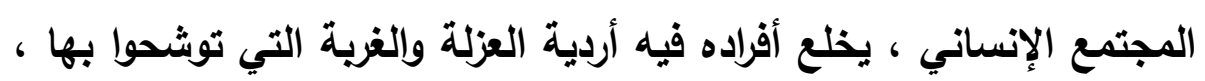

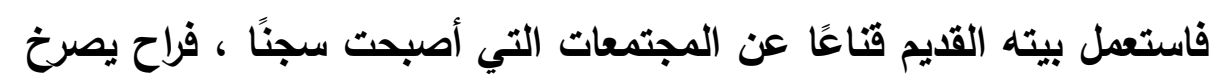

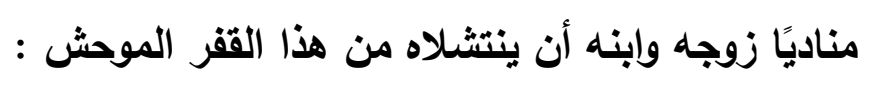

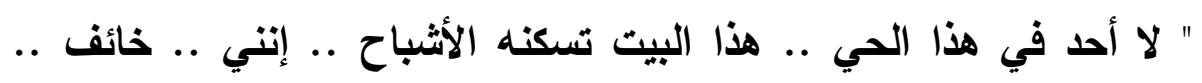
خائف أين أنت يا خضرة ..يا جابر أمسك بيد أبيك ليخرج من هذا الظلام .. الظلام

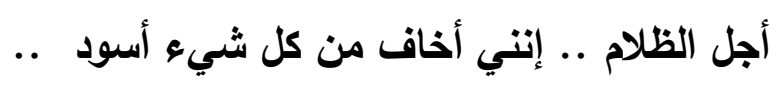

(1 ) مسرحية " ولادة متعسرة ، نصوص مسرحية ص ؛ V، سابق · مهابق

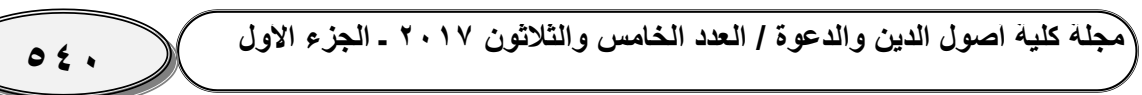




\section{مونودراما المسرح السعودى الروئة واثنكالات الفن الفودي}

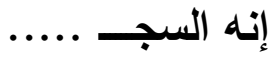

يا إلهي لا .. هذا المكان يسمى سجنًا .. سأجعله كتلة من الضوء"(') ومع ذلك ، فالأمل يحدوه في غد مشرق ، تتبدد فيه ظلمات الحياة ، مع عودة الألفة والمودة والتراحم بين الناس ، لكنه سرعان ما يفيء وقد أصابه اليأس والقتوط ، فتلجلت مشاعره وحشرجت نفسه ، فقرر الهروب والعزلة عن الحياة والأحياء ، وقد ألح على هذه الفكرة في مسرحيته " أنا لست أنا " ، فبالرغم من تعدد مشاهد الصراع إلى أنه بأها بسرد معاناة الإنسان المعاصر ، ورغبته الجموح في مفارقة الأحياء وريما الحياة : " أعينتا تتعب من الضوء .. ها هي العتمة تحيط بنا ..هل نحتاج إلى أن لن نموت لكى نحيا في ذاكرة البعض ..أنا الآن ميث .. أجل .. ميث .. سبعة أشهر وأنا أقطن هذا القبو .. نادرًا ما أغادره .. لا أريد أحدًا .. ألم يقولوا أن الآخرين هم الجحيم .. صدق من قال ذلك .. تحدثث مع أبنائي أكثر من مرة

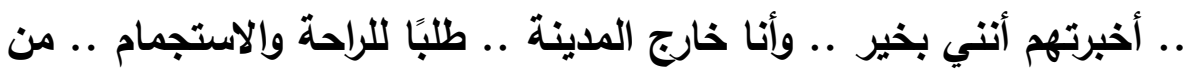

يصدق .. خارج المدينة .. وأنا حقيقة في قلب المدينة "(؟) فأبطاله مسكونون بهواجس نفسية جراء المتفيرات التي طرأت على القيم الإنسانية ، فازدادت معها معاناتهم ، وتتوعت صراعاتهم الفكرية والنفسية ، وإنتهى بهم المطاف إلى الرغبة في العزلة والانطوائية ، والإحساس الدائم

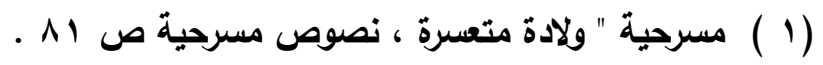

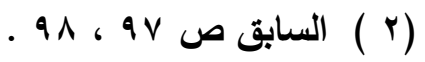


بالوحدة النفسية التحولية ، التي طرأت نتيجة المستجدات المتلاحقة ، فازداد معها شعورهم بفقدان التواصل الروحي والتقبل ، وانعدام الروابط الاجتماعية ، وعجزهم عن إيجاد علائق قوامها الألفة والمودة الصادقة. ويعد الثعور بالوحدة والرغبة في الانكفاء على الأت من أبرز المعضلات النفسية في حياة الإنسان المعاصر ، الأي بدا في مونودراما الصقعبي فاقدًا توازنه العقلّي والنفسي ، متخمًا بالاضطرابات النفسية والسلوكية. وهذا دأب الشخصية التعبيرية في المونودراما ؛ إذ تكون عرضة للتحولات النفسية المفاجئة التي تؤثز في حركة الحدث والصراع ، فتبرز الإنسان المعاصر في صورته الحقيقية من غير خداع ؛ لأ تتكون المسرحية التعبيرية من عدد من المشاهد ، التي لا تلتزم الإطار التقليدي المتعارف عليه في الاراما المسرحية ، لتعبر عن حالات الاستلاب الإنساني ، فتبدو الشخصية سليب الإرادة لا تملك حرية الرأي واتخاذ القرار ، فالكاتب التعبيري يضخم من معاناة أبطاله ، ويبالغ في مواقفهم ، ويفجر كل طاقاتهم الحسية والذهنية

ويكسبها سمة الشمول (1)

(1 ) ينظر : المسرح والقضايا المعاصرة ص ^ץ ، سابق. 


\section{المبمث الثثاني \\ بنية المونودراما في مسرح المقهمبي}

تحوى المونودراما كافة مقومات النص المسرحي ، وينحصر الفارق

بينها وبين المسرحية الجماعية / التقليدية في صيغة المونودراما القائمة على التكثيف من غير إخلال بمقومات العمل شكلًا ومضمونًا ، وقا يتحول الأداء في المونودراما الفردية إلى ما يشبه الأداء الجماعي ، إلا أن المؤدي يكون فردًا واحدًا ، فقد تتعدد الشخصيات فيها ، لكن لا يمنح حق الأداء إلا الا

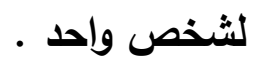

والنص المونودرامي عند الصقعبي تكون من جملة عناصر المسرحية التقليدية ، منها : • الحدث الارامي : غلب الطابع المأساوي / التراجيدي على كل أحداث النص المونودرامي الصقعبي ، وق أتث الأحداث نتيجة تجارب ذاتية ،

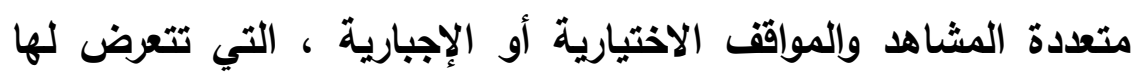
الثخصية ، فتقف مراجعة مواقفها ، محاسبة نفسها ، مترددة بين

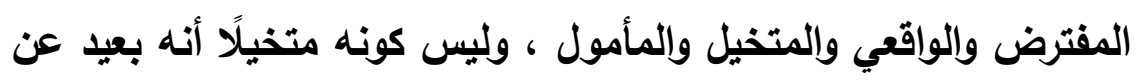
المنطقية ، بل يتأتى من خلال توظيفه للحم والقتاع ، في إطار اختزالي

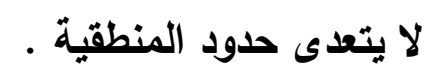

فالمونودراما تتمتع " بالكثافة الشعورية الشديدة النابعة من تركيز الحدث الارامي في شخصية واحدة ، تلح على وجدان المتفرج طوال العرض ، وريما كانت الكثافة الشعورية أحد عوامل الجذب الرئيسية فيها ، فهي واجي 


$$
\text { مونودراما المسرح السودى الروئية }
$$

للمسرحية العادية كالقصة بالنسبة للرواية ، في عالم الأدب الروائي من ناحية التركيز الشعوري" (1)

وتكاد تنحصر السمات البارزة لنصوص الصقعبي - مع ما تعانيه شخصياته من تمزقات نفسية و اضطرابات إدراكية وسلوكية - في اختزال

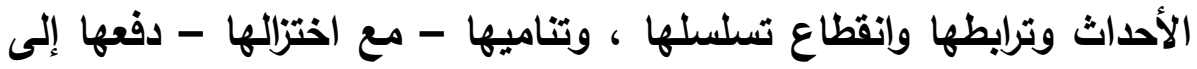

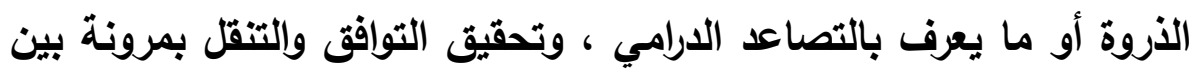
المشاهد ، وإن اضطريت الأحداث في بعضها وتداخلت ، كما في مونودراما "

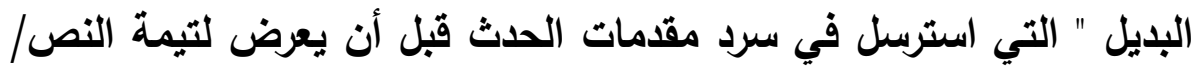

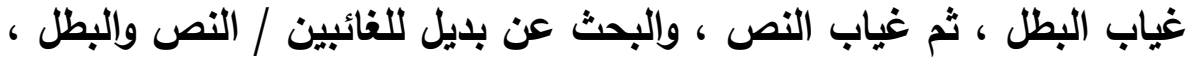

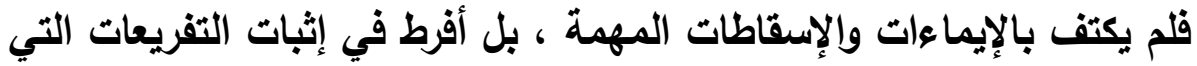

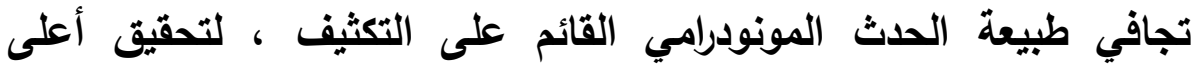
مستويات الجذب والمعايشة للمتلقي .

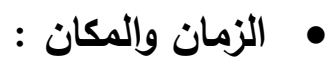

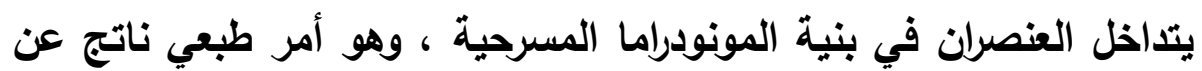

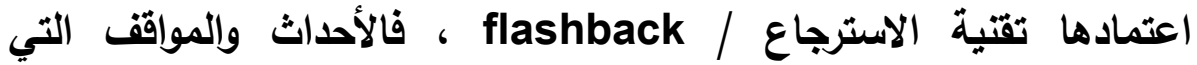
تستدعيها الشخصية تتعدد أفضيتها وأزمنتها ، مما يحدث ذلكك التمازج . والزمن في المونودراما زمن نفسي غير مقيد بلحظة تاريخية معينة

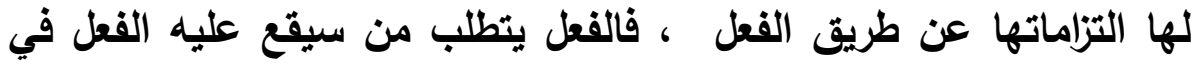
(1 ) التيارات المسرحية المعاصرة ص IVY ، سابق . 
إطار من التوتر والمقاومة ، وهذه حلقة مفقودة في المونودراما ؛ لأنها تبرز

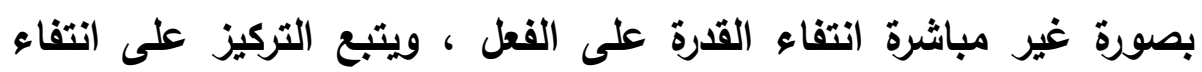

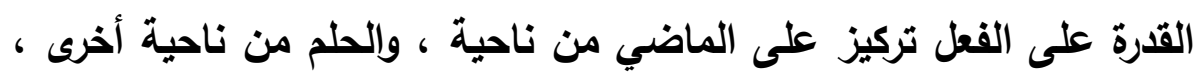

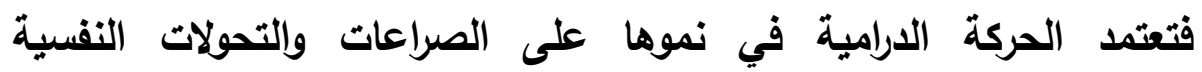

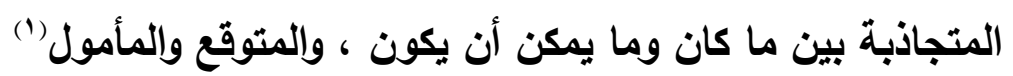

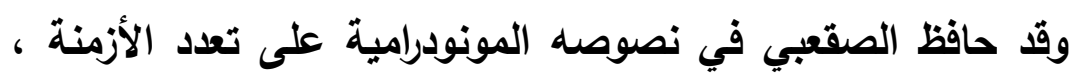
ففي" واحد صفر " تتزاحم الأزمنة وتتقاطع ، فيتنقل بحرية بين الآني والآتي

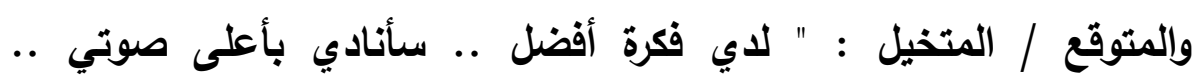

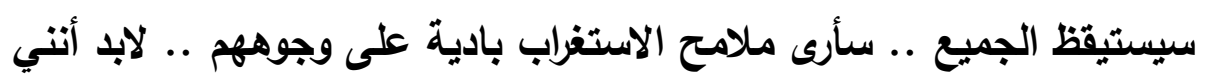

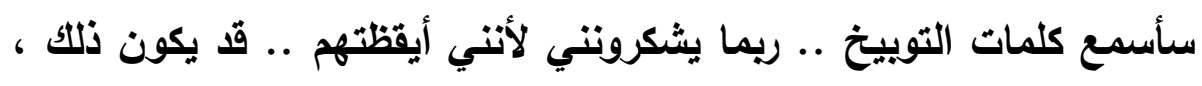

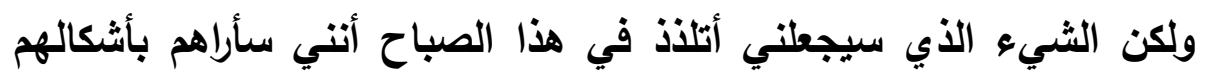

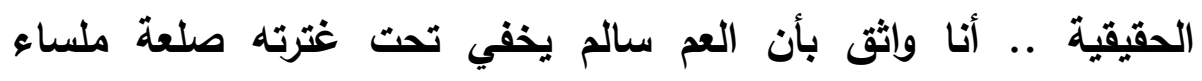

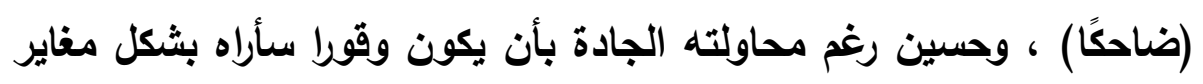

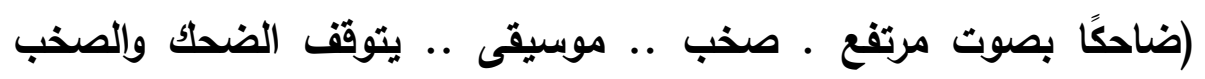

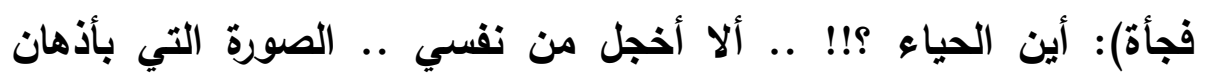

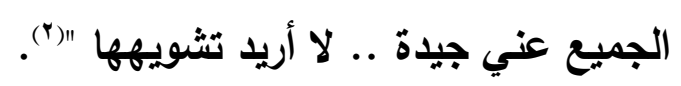
فانتفاء القدرة على الفعل أو التردد في الإقدام عليه ، بجاتب تزاحم

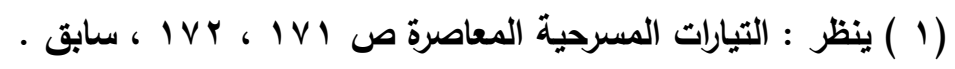

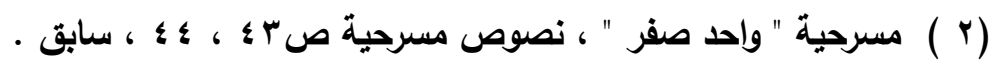
$0 \leqslant 0$

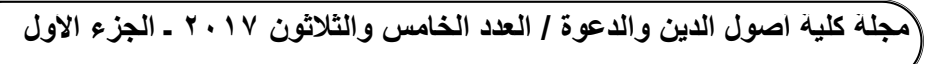


الصراعات النفسية ، وغياب السكينة والطمأنينة نظرًا لفردية الأداء ، وهيمنة القلق والتوتر الغززي ، ولا كل هذا التداخل الزمني الذي ساعد في إنماء الحركة الدرامية وتظورها.

فالطرح الدرامي للزمن لا تحده قيود أو قواعد ، عدا استعداد المتلقين لتصديق أي بنية زمنية يستخدمها العرض أو يصرح بها في أيه لحظة ، وتستخدم تقاليا الزمن الواقعي وسائل درامية ، لخلق نوع من الإحساس بأهمية أداء

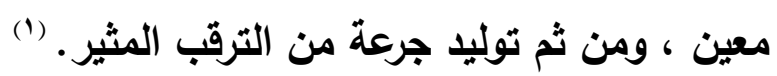
كما كان للاسترجاع أو اجترار الماضي ، وامتزاجه بالآني والمتوقع

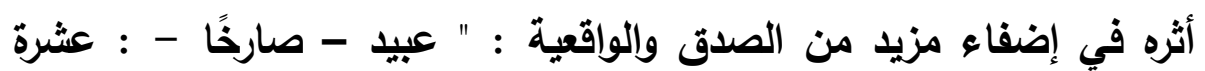
آلاف ريال !! ينظر إليها بسعادة .. أجل .. هذه هي الشمس التي أشرقت .. هي لي .. ملكي .. قد استيقظت باكرا .. خرجت لأعمل .. أبحث عن رزفي

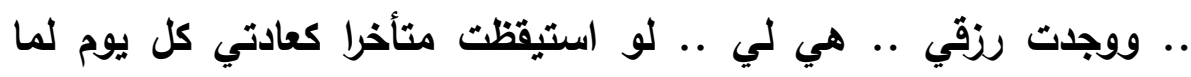
حصلت عليها .. ويسبقي إليها غيري .. إذن فالقضية أن هنالك سباقا .. وأنا الأي سبقت الجميع "(") ومـع من هذا التاخل الزمني الأي صاحب التوترات النفسية وهواجس أبطاله إلا أن الزمن الآني كان أكثر حضورًا في جميع نصوص عبد العزيز

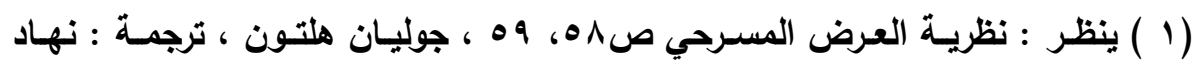

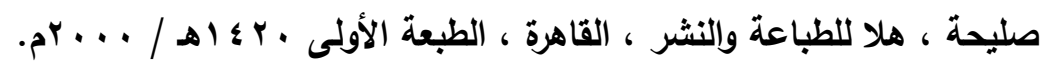

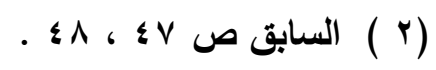


الصقعبي المونودرامية ، وإن اتخذ هذا الزمن بعدًا ملحميًّا نفسيَّا ناتجًا عن

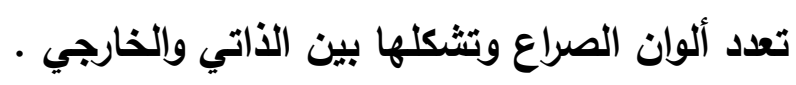

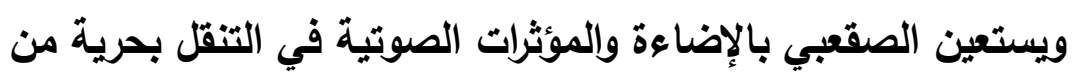

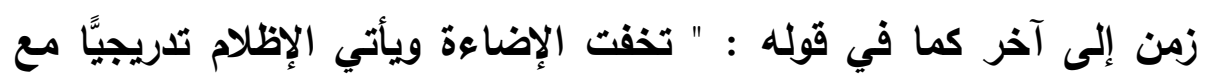

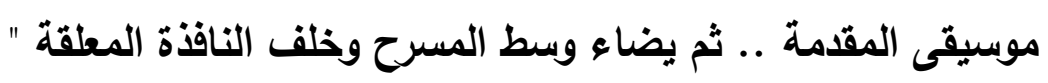

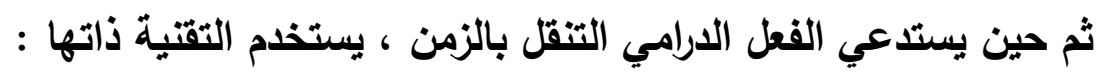

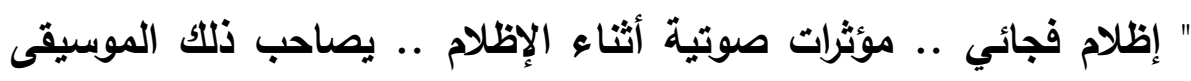
الحزينة التي جاءت في المقدمة .. تخفت الموسيقى .. وتضاء خشية

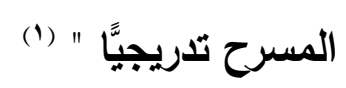

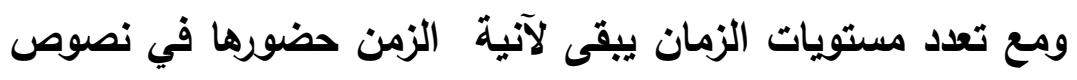

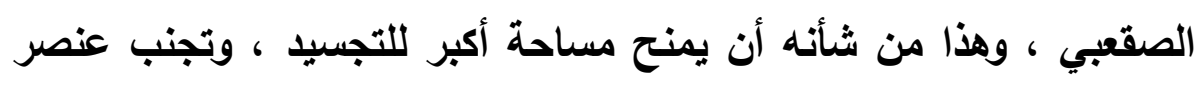

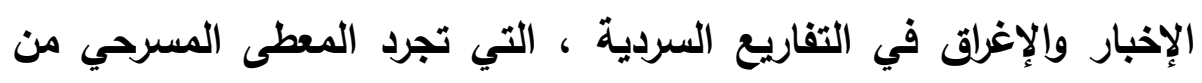

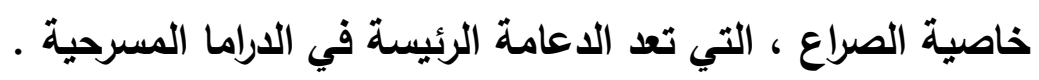

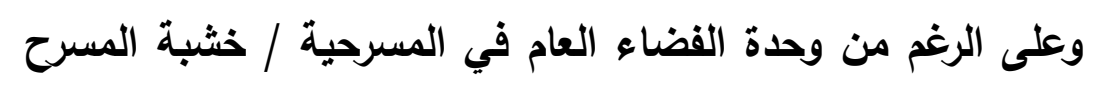
إلا أن الأمكنة تتعدد مستوياتها عن طريق اللغة السردية ، ويمثل الفضاء

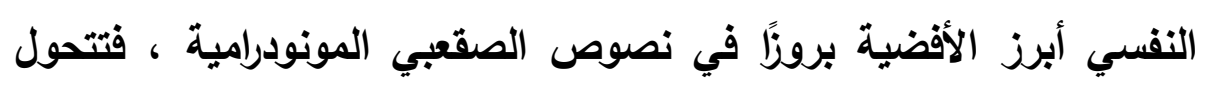

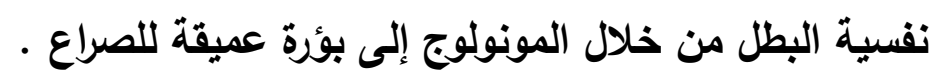

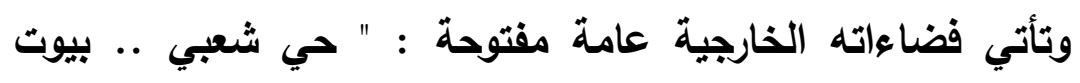

(1 ) مسرحية " البديل " ، نصوص مسرحية ص \& Y 1 ، IV 1 ا، سابق .

\section{$0 \leqslant V$} مجلة كلية اصول الدين والدعوة / العدد الخامس والثلاثثون V ا ب ـ الجزء الاول 


\section{طينية بجانب بعضها.. شارع صغير "(1)}

وقد تأتي مغلقة :" المنظر : غرفة لبيت طيني قديم .. كثير من الغبار .. كثير من الأساس المهمل .. عش عنكبوت في أعلى السقف .. صوت أغنية

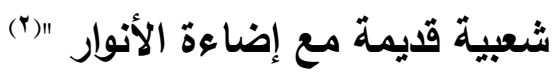
فتلك الأماكن الخارجية التي اختارها الصقعبي تحمل دلالات نفسية واجتماعية، فالأثكال والأدوات داخل المكان مثلت عاملًا مهمًّا في ترجمة التيمة الارامية .

ويستخدم الصقعبي في تشكيل فضاعات العرض المسرحي (السينوغرافيا ) التي تعني : " فلسفة علم المنظرية الذي يبحث في ماهية كل ما على خثبة المسرح ، وما يرافق فن التمثيل المسرحي من متطلبات ومساعدات تعمل في النهاية على إبراز العرض المسرحي جميلاً، كاملاً، متناسقًا ومبهرًا أمام الجماهير "(") ، وقيل إنها تعني : " فن تنسيق الفضاءهاء والتحكم في شكله بغرض تحقيق أهداف العرض المسرحي الأي يشكل إطاره

(1 ) مسرحية " واحل صفر " ، نصوص مسرحية ص اء؛ ، سابق .

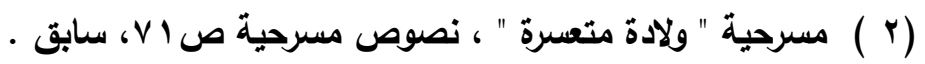

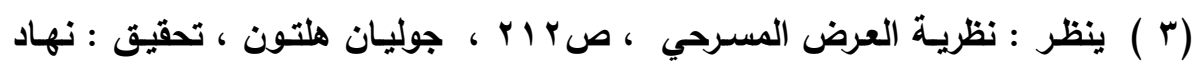

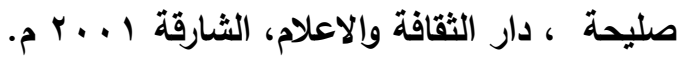




\section{مونودراما المسرح السعودى الروية والثكالات الفن}

الأي تجري فيه الأحداث " (1) .

فتنظيم الفضاء المسرحي بأبعاده وعناصره المتنوعة يخدم بشكل مباشر الروية الدرامية ، ويعمل على سرعة ترجمتها وتحقق إدراكها لاي المتلقين ، وهذ يجلي التعالث الوثيث بين الحدث الدرامي ، وأساليب ( السينوغرافيا ) والأداء المسرحي ، والسينوغرافيا في المسرحية الجماعية تعمل على وحدة الزمان والمكان ، ولا يتحقق ذلك في المونودراما القائمة على الاستدعاء ، الأي يمنح الزمان والمكان سمة التعددية.

\section{: •}

عمد الصقعبي إلى اختيار شخصياته من واقع الحياة المعاصرة ، وأظهرها متخمة بالهموم واللهواجس النفسية و المعضلات المجتمعية ، وجنح إلى تحديد أبعادها الجسمية والنفسية : " ياخل بملابس النوم يبدو وكأنه مستيقظ وئه لتوه "(ז) ، " يذخل الممثل .. وقد لبس ثويًا ( أبيض ) ويشتًا ، وعقالا وغترة (ب) " بيضاء

كما استطاع أن يزود شخصياته بأفعال وحركات من شأنها تسهيل ترجمة

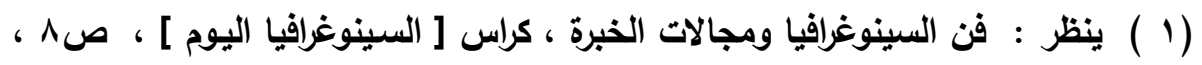

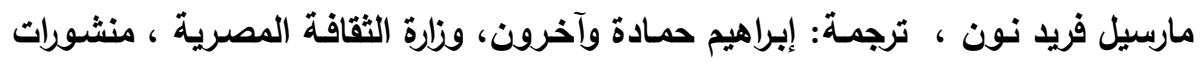

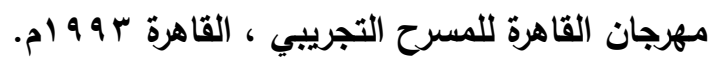

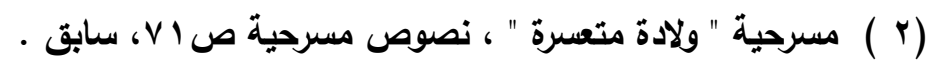

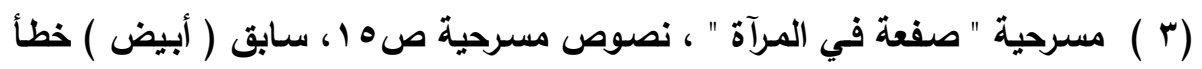

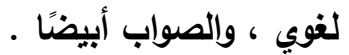

$0 \leq 9$

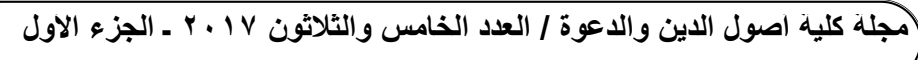


الفكرة والكشف عن جواتب الثخصية : " يتحرك في الغرفة كأنه يرقص.. سنرقص سويًّا.. ونغني ونضحك ونبكي .. بلا تشنج ....... يبدو وكأنه أصيب بالاوار أثناء رقصه .. ثم بعد أن يجلس ويهـأ قليلا : ما الأي أصابني .. بأت أهذي .... يتجه إلى الباب الذي دخل منه .. يحاول أن يقتحه .. يسمع صوت انقضاض جزء من البيت .. يتضح أن الباب سد بأنقاض الغرفة التي سقطت " (1) وحرص الصقعبي على تطور شخصياته ونموها من خلال تعدد المواقف والصراعات ، وتنقلات الزمن وتعدد مستوياته وتداخله مع الفضاءات ، وقد كان لهذا النمو دوره في محاولة ملء الثخصية فضاء المسرح. ونهوض المونودراما على شخصية واحدة يسهم في تشعب وتعدد ألوان الصراع النفسي ، وإن كانت وحدة الأداء أحد أبرز الإثكالات التي تلاحق هذا الفن ، ما حدا بالكتاب إلى ابتكار الأدوات واللوسائل ، التي تمكنهم من التظلب على رتابة وحدة الأداء والصوت المنفرد . مابل

\section{àll|}

تمثل اللغة في كافة النتاجات الأدبية أداة خلق وإيجاد ، ولابد للغة مونودراما المسرح أن تنتقل من كونها لغة إبلاغية تقريرية ، إلى لغة

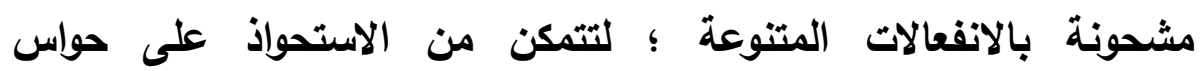

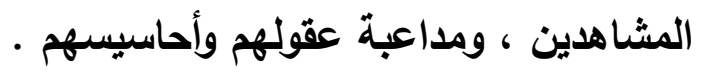

(1 ) مسرحية " ولادة متعسرة " ، نصوص مسرحية ص1^ ، 19 ، سابق • ๑०.

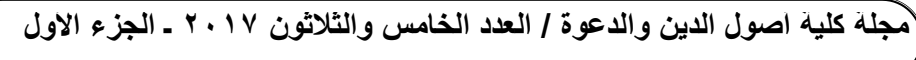


ولغة المسرحية بثكليها الفردي والجماعي خطاب لغوي مؤجل ، بمعنى أنه خطاب حرفي أنجز في هيئة أدب مكتوب مقروء ، وصوتي في كونه كلام على ألسنة المؤدين يسمعه الجمهور ، فماب وجدت المسرحية

(1) إلا لتشخص .

والخطاب المسرحي يجمع في لغته بين مناجاة العقل والصراع المنطقي ، ومداعبة العواطف واستثارتها ، ولاشتماله على عنصر المشاهدة كان تأثير تلك اللغة أقوى إذا قورن بالنصوص السردية المقروعة ، " فلغة المسرحية تحقق للمشاهدين ماهية مقاييس الإمكانية والاحتمالية "(؟) ، غير أن اللغة وحدها غير قادرة على خلق العالم الافتراضي ، بل لابد أن تتعاضد معها في هذا السينوغرافيا وأسلوب التشخيص. وقد نسج الصقعبي مسرحياته جميعها باللغة الفصحى ، ونأى بنفسه وأدبه أن يتقوقع في العامية المحلية ، فالفصحى أحالته نصيًا منفتحًا قادرًا على تقديم الأفكار وإيصالها ممزوجة بالعاطفة والخيال ، قادرة على التلاقي مع أحاسيس المشاهدين ، والزج بها في أتون الحبكة الدرامية .

(1 ) ينظر : أزمة المسرح السعودي ، ص · ب ، ياسر مدخلي ، طبعة دار ناشري للنشر

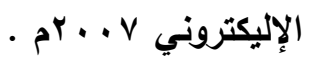

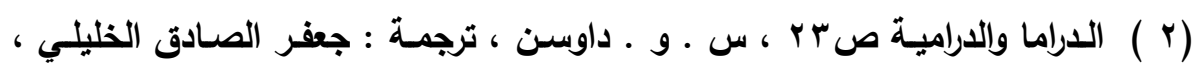

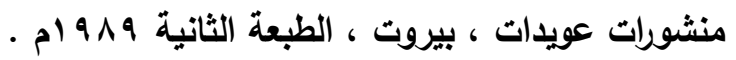




\section{البهش الثشاله \\ هونودراها الصقعبي .. إنكالات ومعالجات}

سبق الحديث عن أن المونودراما تحوي كافة مقومات النص المسرحي ، وينحصر الفارق بينها ويين المسرحية الجماعية / التقليدية في صيغة المونودراما القائمة على التكثيف من غير إخلال بمقومات العمل شكلاً ومضمونًا ، فقد يتحول الأداء في المونودراما الفردية إلى ما يشبه الأداء

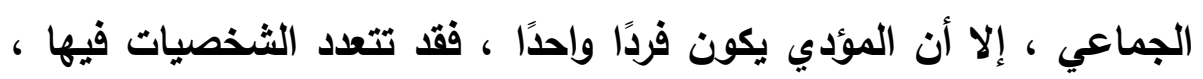

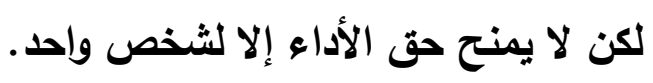
ومن ثم فهي لا تمثل - كما قيل - هرويًا من الفعل الجماعي ، الأي هو أبرز ميزات الفن المسرحي ، لكن طفا في الساحة النقدية القول بأن مبررات وجود المونودراما في الساحة الإبداعية العربية " واهية فهي تأتي لتقوية الحس الفردي ، بينما المسرح عمل جماعي ، ثم إن كل من يعجز عن جمع مجموعة من الممثلين لجأ إلى المونودراما لسهولتها من الناحيتين القنية والانتاجية " (1)، وتعالت الأصوات التي تنادي بأن المونودراما " لا من من تلخل ضمن تقسيم ومسميات الأدب المسرحي ، فالبناء التقليدي للاراما يعتمد الصراع عنصرًا أساسًا بين قوتين أو نقيضين ، فأين الصراع في الشخصية

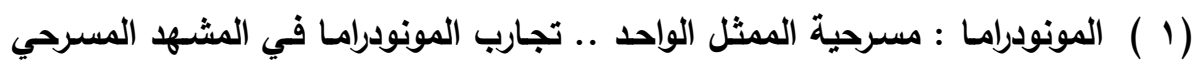

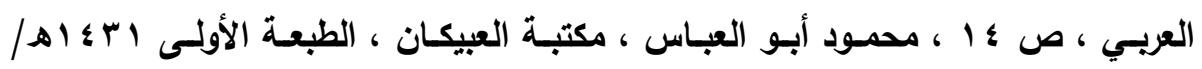


الواحدة ، وهي تجسد أفكارًا من وجهة نظر واحدة ؟ "(1) . بيد أن تلك التكهنات مرادها وأد التتويع والتجريب في العمل الدرامي المسرحي ، وإلا فإن تطورات الحياة المعاصرة المتلاحقة حدت بالمونودراما أن

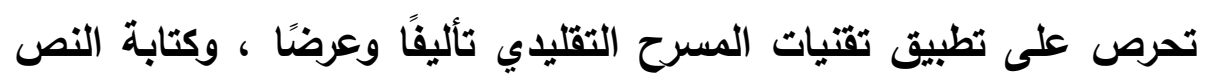
المسرحي الفردي " لا تبتعد كثيرًا عن النص التقليدي ، فهي تحتاج إلى تقتيات الكتابة المسرحية التقليدية ، من خلال الوضعية الاستهلالية ، والوضعية الأساسية ، وحبكة رصينة ، وحدث صاعد ، وذروة وحدث متهاو ، وحل ضمن قصة خيوطها تتشابك ، وهي تتحرك بشخصية واحدة ، تقدم تفاصيل مقتعة تشعرك بأنك أمام جوقة ممثلين وليس ممثلا واحدًا ـ إذن المونودراما مسرح نوعي ، وهي إفراز فعلي لتطور المسرح برغم الاختلافات

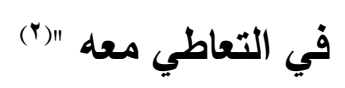

على أن ذلك يتطلب مبدعًا واعيًا بمجتمعه ، ذا تفاعل حي مع أفراده

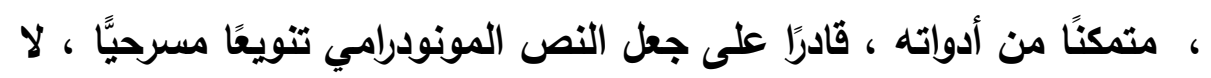
انحرافًا للنص الإبداعي عن مساره ، إذ " الخوض في غمار المونودراما من هن قبل المسرحي المختص يعتبر امتحانًا حقيقيًا له في مجال فهم المسرح

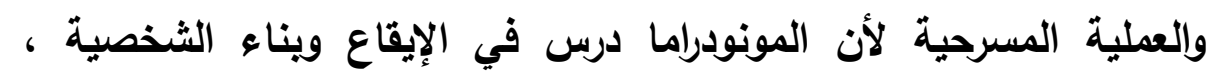
وتكثيف الأفكار ويناء الفضاء المسرحي وكل ما له علاقة بالعملية

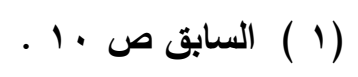

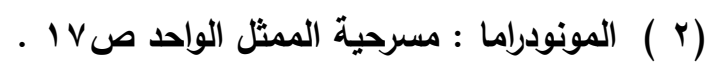

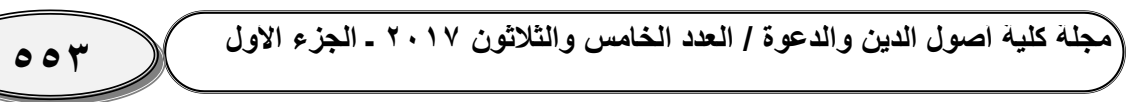


المسرحية " (1) ، وإلا غدا نصه حالة من حالات السرد ، تتجافى وتقنية

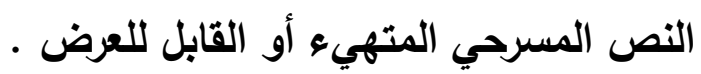

\section{وهن أبرز الإشكالات التي تواجه هونهودرامها المهرح :}

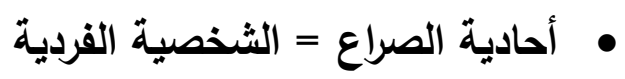

لاثكك في أن المسرحية فعل جماعي قائم على التعددية في الأداء ، وارتكاز

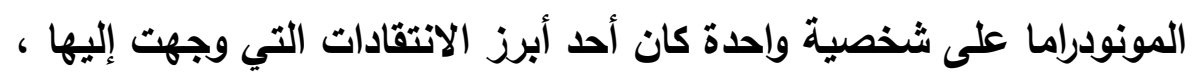

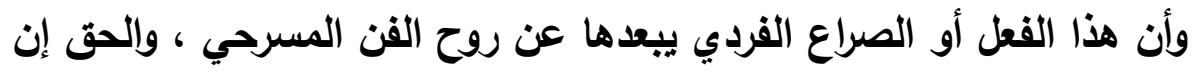

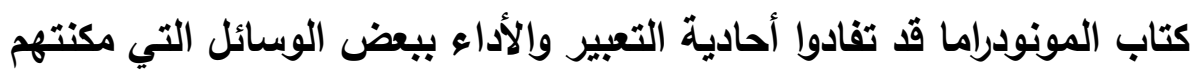
من كسر هذا الحاجز ، منها :

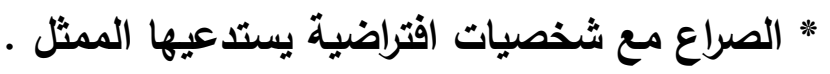

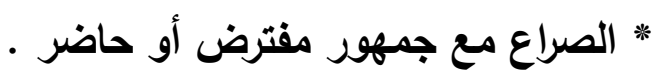
* الصراع مع الذات و استحضارها بواسطة المرآة أو الصورة.

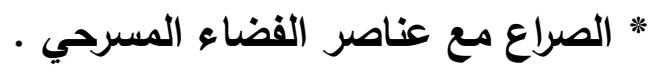
وقد استعان الصقعبي بتوظيف بعض هذه الوسائل ليتظلب على إثكالية

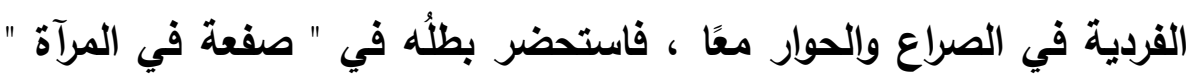

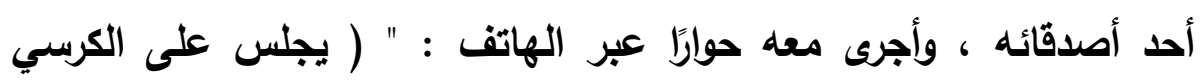

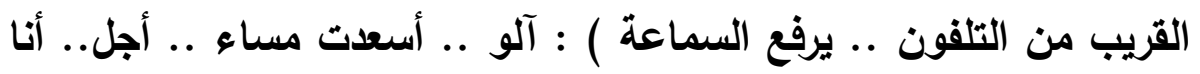

(1 ) المثل الواحد على مسارح المهرجانات (حزين) ، جمال آدم ، مجلة البيان الإمارتية

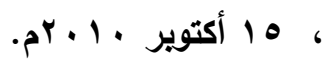

\section{$\bullet \bullet \leq$}

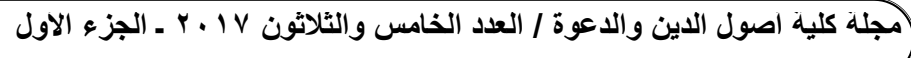


هو.. مساء البارحة لم أستطع الحضور .. كنت متعبًا .. أبدًا مجرد وعكة

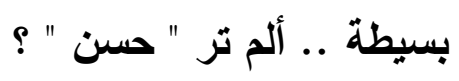
كنت معه ! .. أين ؟ .. ماذا ؟ .. ولماذا ذهبتم معه ؟ .. خطوية من ؟ .. خطوية " حسن " ! .. تقصد خطويتي أنا ! .. ذهبت معه منذ أيام وطلبنا يدها .... لحسن ، لا .. بل لي .. إذن فقد خدعني " حسن ! .. اسمع أريا أن أرى " حسن " الآن .. لتقل له إنتي مريض .. لآ رجاء أريده .. سأكون

بانتظاره " (1) (1)

فتخيل الغائب واستدعاؤه من وسائل معالجة وحدة الصراع في المونودراما ، وحضور الهاتف - هنا - لا يعني انقضاء المسافات وإلغاؤها بين المتحدثين ، فهو لا يعدو وسيلة للحوار بين أناس تفصلهم مسافات زمانية ومكانيه ، وريما روحية .

ومن ذلك استحضار البطل - في المسرحية نفسها - والد الفتاة التي

أقبل على خطبتها: " العم عبدالله كان يسألني .. وكنت أجيبه .. وأخيرًا قال : ( مغيرًا نبرة صوته ، متصنعًا شكل رجل كبير ، وقد جلس على الكرسي ) الممثل : يا ولاي .. يسعدني أن تكون زوجًا لابنتي .. ولكن يجب أن نعرف رأيها .. الأسبوع المقبل بإذن الله ، ومثل هذه الليلة ستعرف الرد " (†) ،

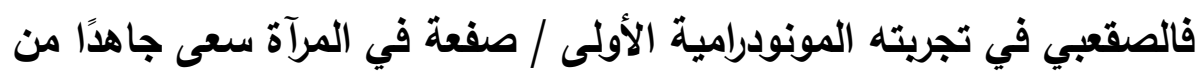

(1 ) مسرحية " صفعة في المرآة " ، نصوص مسرحية صل 1ا، V V ، سابق .

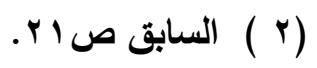


خلال الثنائية المتخيلة أن يتظلب على إثكالية وحدة الصراع والحوار ،

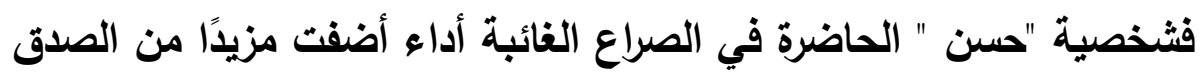

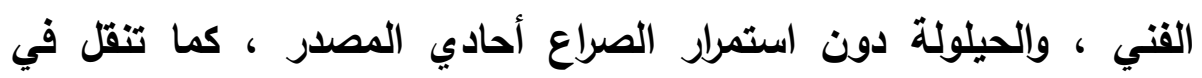

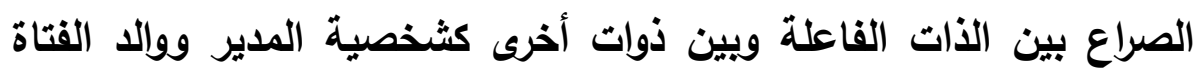
وصديق آخر ، ومن ذلك استدعاء البطل في " البديل " شخصية مخرج

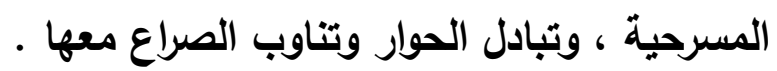

وقد يدير الصراع بين البطل وجمهور مفترض كما صنع في مسرحيته

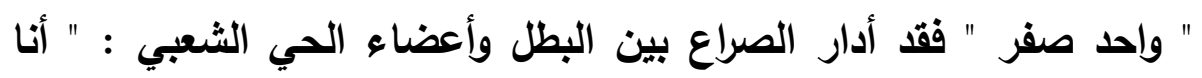

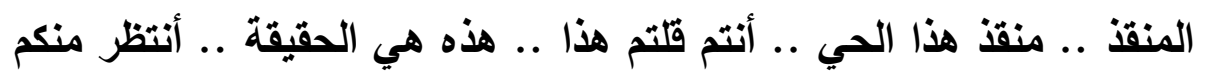

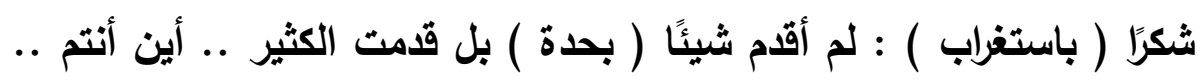

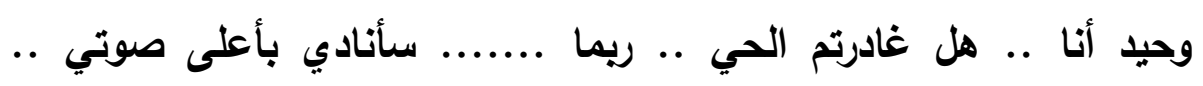
سيستيقظ الجميع .. سأرى ملامح الاستغراب بادية على وجوههم .. لابد أنني

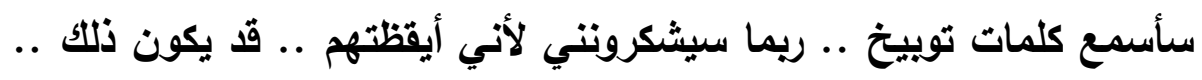

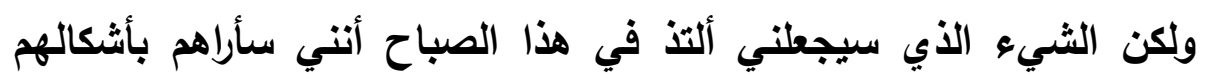
(الحقيقية "(1)

فهذا العالم المتخيل عمل على التخفيف من تبئير الصراع في ذات واحدة . وقد يستعين بتعدد الأصوات من غير حضورها على خثبة المسرح

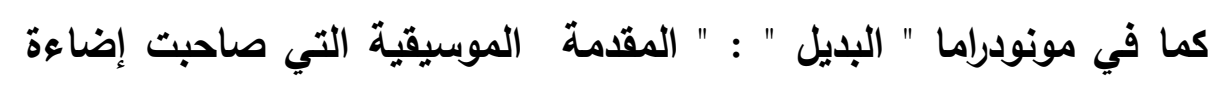

(1 ) مسرحية " صفعة في المرآة " ، نصوص مسرحية صه 1، IV ، المابق . 007 مجلة كلية اصول الدين والدعوة / العدد الخامس والتلاثتون IV . ـ ـ الجزء الاول 
الأنوار .. توحي بالحزن .. هادئة .. لا أحد على المسرح . صوت ا : أرأيتم كيف اختفى البطل ؟! صوت : من تقصد ؟

صوت 1 : ومن غيره .. ذلك الأي حفظت خثبة المسرح تفاصيل قدمه . صوت ب : مساء البارحة كان هنا .. ولكن كيف اختفى ؟ ! " (1) ، فتنوع الأداء الصوتي يمثل عاملًا مساعدًا في التمهيد للصراع ونقطة الانطلاق ، وكسر حاجز وحدة الأداء ، من خلال السرد الحواري الذي يمثل أبرز أدوات

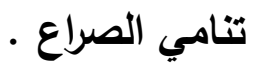
ومن وسائل معالجة ذاتية الأداء والصراع - عند الصقعبي - خلقه لعالم افتراضي عن طريق تشخيص عناصر الفضاء المسرحي ، من ذلك مخاطبة البطل الغرفة القابع فيها : " جبران : لقد تهاوى البيث .. سقطت

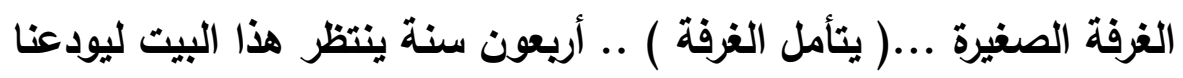
. . ودعناه قسرًا .. وها هو يودعنا ( بدا عليه الخوف ) .. لا .. لا يا عزيزي

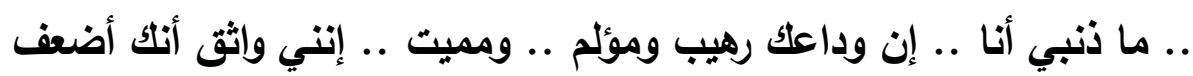
من أن تكون مسرحًا لحياة جديدة .. ولكن امنحني شيئا من الوقت حتى إنى أغادرك .. أريد أن أغادر .. ولك الحرية في أن تنقض وقتما تشاء " (r). ومن وسائل المعالجة استحضاره ذات البطل عن طريق المرآة : "

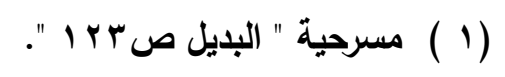

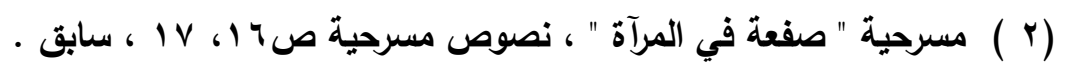

\section{O०V}

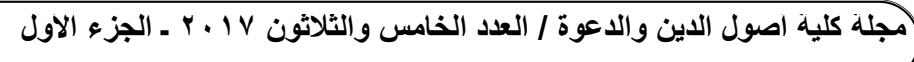


ياخل الممثل ... ويقف أمام المرآة : رائع أنا .. أجل أنا رائع .. انظر بعينيك

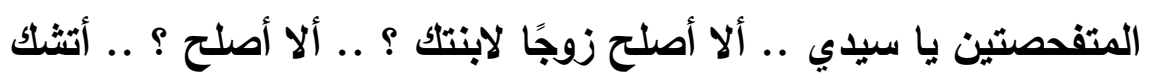

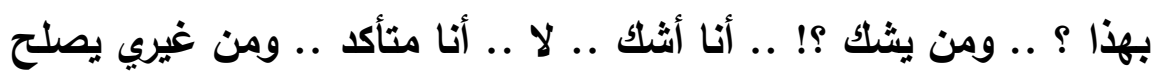

زوجًا لابنتك ؟ب! (1)

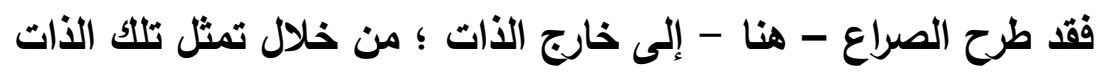

وانقسامها عبر المرآة ، فالصراع وإن كانت تصنعه نفس واحدة ، إلا أنه انعكاس لصراعات متعددة الأطراف ، وإن بذا من خلاله الإيغال في الأتية ، والاهتمام بالخلاص الذاتي دون الجماعي ، وهذا ما تنماز به المونودراما.

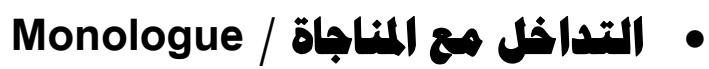

لقد كان لظهور طائفة الرومانسيين في الغرب إبان عصر النهضة أثره البين في تعميق الصلة بين المونودراما وتقتية المناجاة أو حديث النفس ، فقد أوجدوا تلاحمًا بينهما ، في إطار يخدم قواعد الرومانسية التي تتزع إلى لى الفردية ، وإلى حرية التعبير عن طريق مؤدِ واحد ، فالكاتب الرومانسي عمد إلى أن تقوم الشخصية الفردية بالتعبير عن كل دواخله وشواغله . وتتلاقى المونودراما والمونولوج في أن كلاهما ينبع من شخص واحدا ل

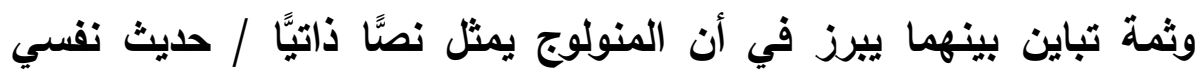
قصير داخل العمل السردي الجماعي ، فالمونولوج - وإن كان حديثًا نفسيًّا تؤديه الذات - إلا أنه يفترض أن يكون داخليًّا .

(1 ) مسرحية " ولادة متعسرة " ص9 ^ ، ، 9 سابق .

$00 \wedge$

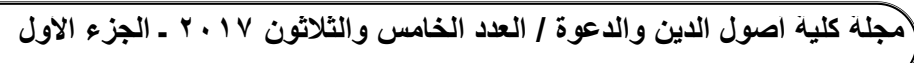


والمونودراما حديث نفسي مطول يؤديه فرد واحد ، تقوم على أسس فنية

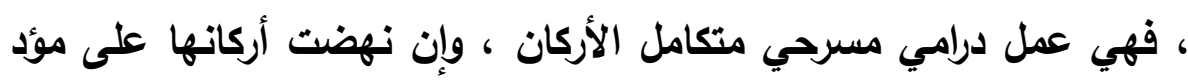
واحد ، تتعدد فيها الثخصيات من خلال استحضارها ، وقيام البطل بتقص

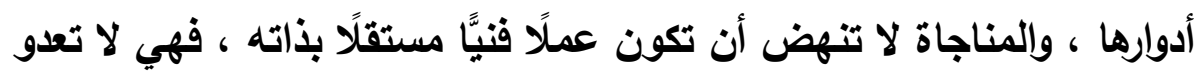

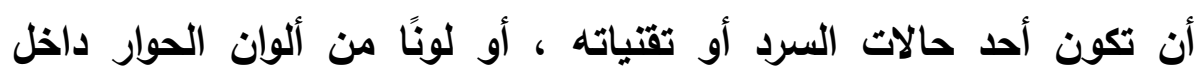
المسرحية الجماعية . الكون الات

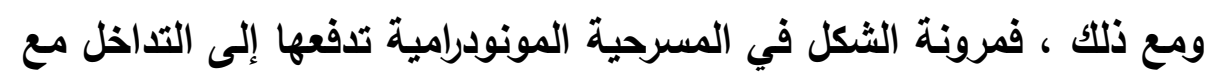
المونولوج في حالة ضعف إمكانات الكاتب .

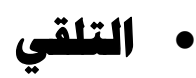
يتمثل التددي الأكبر أمام الفنون التمثيلية - لا سيما المونودراما - في القدرة على إقامة نسث تواصلي مع جمهور يبحث عن المتعة الفنية والفكرية.

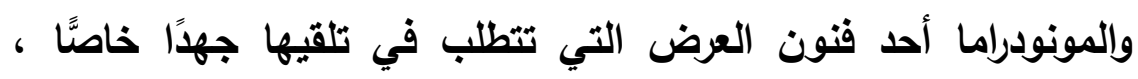
يتمثل في استحضار جمهورها وتخيله المفقود / الغائب لمتابعة الأحداث

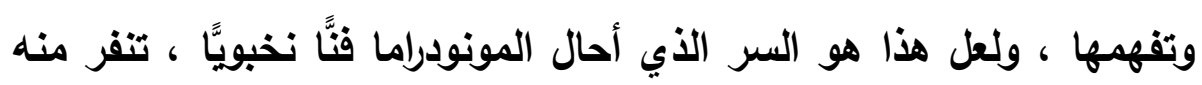
العامة ، وينجذب إليه الخاصة.

والجمهور هو سر ديمومة الفنون - لا سيما المسرح - ؛ لذا كان لزامًا

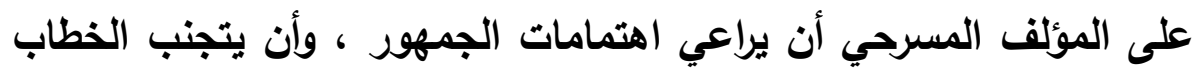

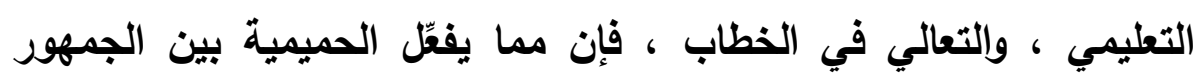

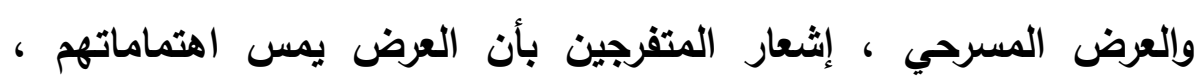

\section{9} مجلة كلية اصول الدين والاعوة / العدد الخامس والثلاثتون Y ا ب ـ الجزء الاول 
والمؤلف لسان حالهم .

ومن ثم كانت محاورة الجمهور ، وتوجيه الخطاب المباثر إليه أحد أبرز

أدوات الكاتب لتفعيل أثر الاستجابة ، وقا صنع الصقعب ذلك في أكثر مونودراماته :( يتجه الممثل للجمهور ) سند : أسعد الله مساءكم ومساءكن ومساء كل من نشر الابتسامة على هذه الأرض .. اسمي " سند " جميل هذا الاسم .. واثق من ذلك .. اسم سهل ممتنع .. ثلاثة أحرف تقرأ فقط من اليمين إلى اليسار فقط .. أتدرون لماذا أقف أمامكم الآن ؟ " (1) ، فالحديث المباشر مع الجمهور وطرح الأسئلة عليه ، واختيار اسم الثخصية وتحديد مسار قراعته الصحيحة " سند " / دنس يعمل على جذب انتباه الجمهور ، واستجلاب تفاعله ، ودفعه إلى متابعة الفعل الدرامي ، وردود الأفعال التي تصدرها هذه الشخصية ، التي قد تحمل التقيضين. ويُعد المؤلف عن السردية والإخبار في المونودراما من شأنه أن يبعث على تحقيق عنصر الجذب ، وتملك حواس المتلقي ، والإغراق في السردية حتمًا - سيجرد المونودراما من الصراع ، الأي يعد المكون الرئيس لأي عمل درامي ، ويحيل النص المسرحي في لغته أقرب إلى الشعر ، " فيغري المتلقي بجرس الكلمة ، أو اختزال الصورة الثعرية ، أو اللجوء إلى تعابير مجازية تدغدغ بعضًا من هواجس المتلقي ، فيصبح مفعول الدراما آنيًا أو قابلاً للنزاع

(1 ) مسرحية " البديل " ، نصوص مسرحية ص \& ب ا ، سابق .

07.

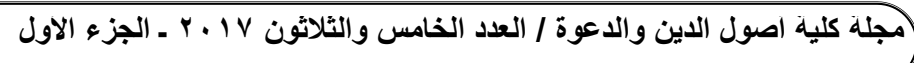


في أي لحظة ، أو أنه يزول بزوال المؤثر " (1) ، وتجنبًا لذلك ينأى عن

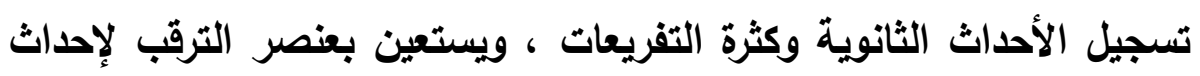

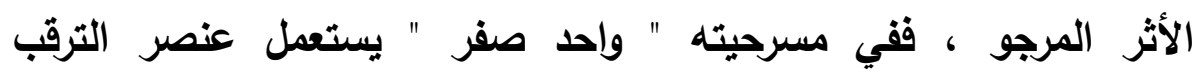

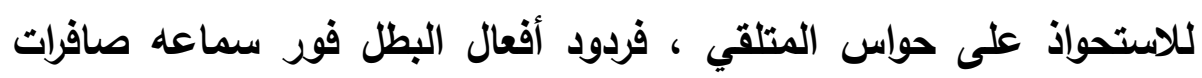

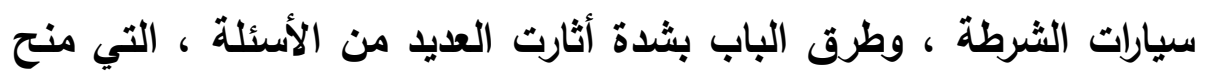

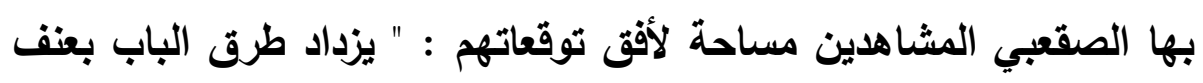

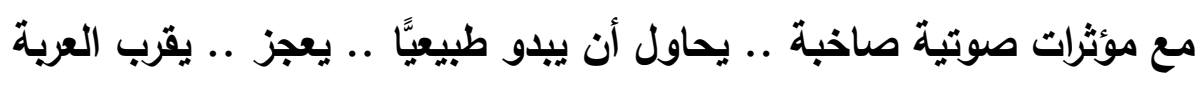

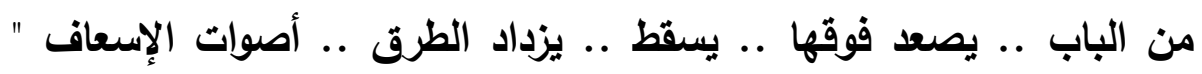

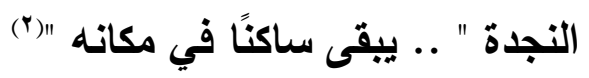
وتعد ( السينوغرافيا ) أحد أبرز أدوات المؤلف المسرحي في تحقيق الماني

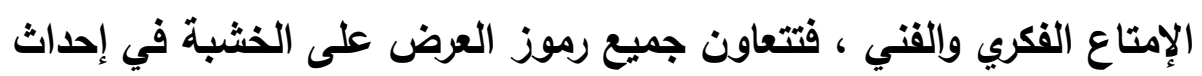

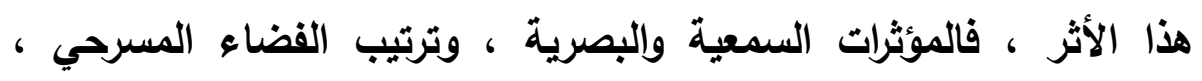

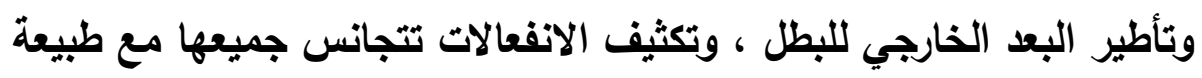

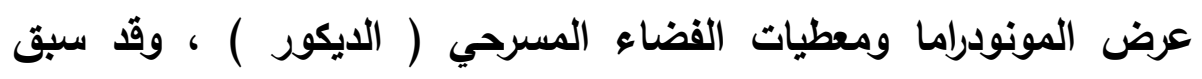

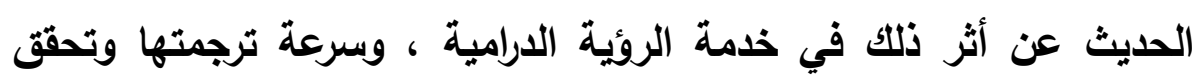

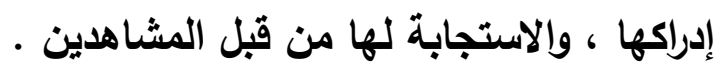

(1 ) المونودرامـا : مسرحية المثثل الواحد .. تجارب المونودرامـا في المشهـ المسرحي

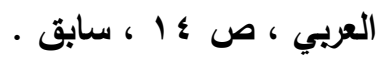

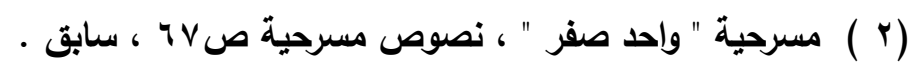

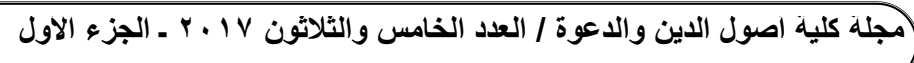


وهناك نوع أخر من ( السينوغرافيا ) يطلق عليها ( السينوغرافيا

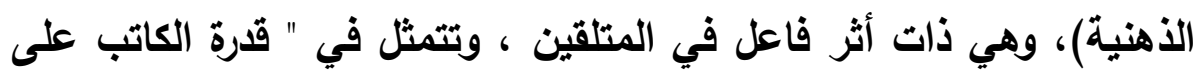

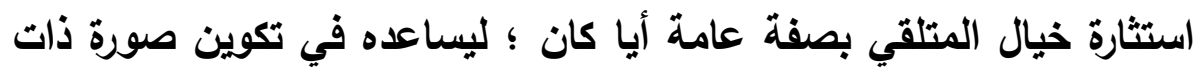
أطر خاصة بالعمل الأدبي المقروء ، من حيث الزمان والمكان والحدث الثان

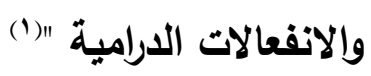
وتتحد كل هذه الوسائل ، في إطار يشي بامتزاج المسرح والسينما جميعًا في

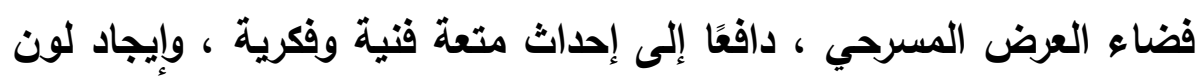

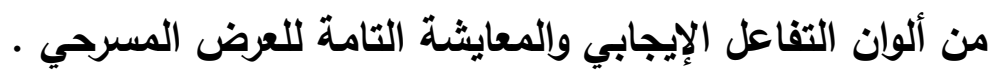

(1 ) السينوغرافيا .. فن تثكيل الصورة المسرحية ، د. كمال يونس ، رابطة أدباء الثـام

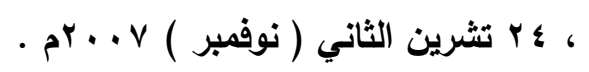
http://www.odabasham.net/\%D9\%81\%D9\%86\%D9\%88\%D9\%86/ .53381-\%D8\%A7\%D9\%84\%D8\%B3\%D9\%8A\%D9\%86\%D9\%88

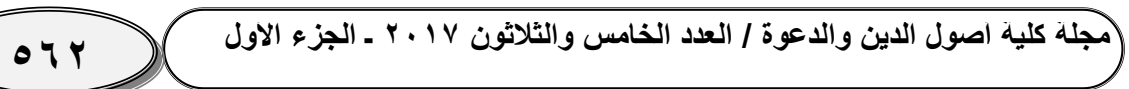




\section{الخاتمة}

الحمد لله رب البريات ، بنعته تتم الصالحات ، ويتوفيقه تنال الرغبات ،

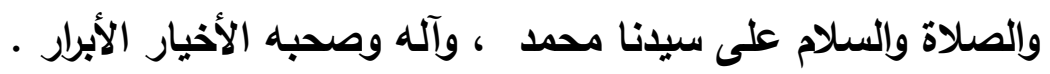

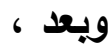

فالفن المسرحي يمثل المرآة الحقيقية ، التي يتعرى فيها الواقع السياسي

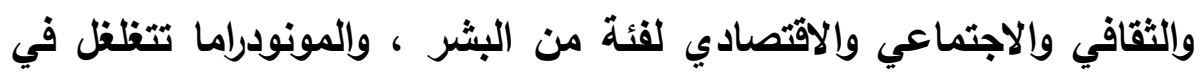

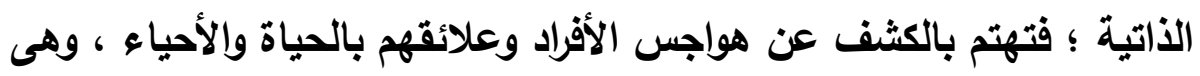

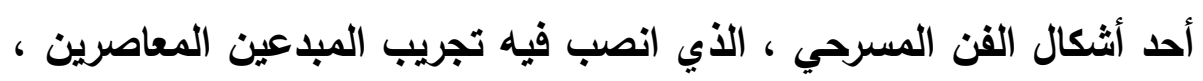

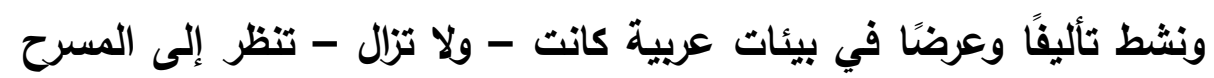

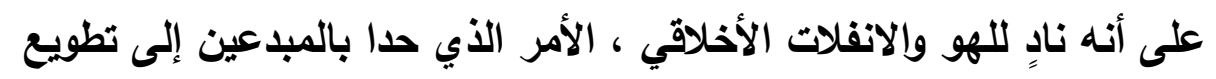

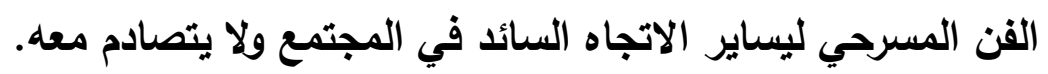

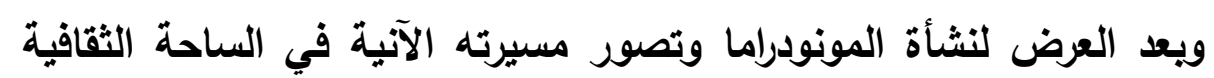

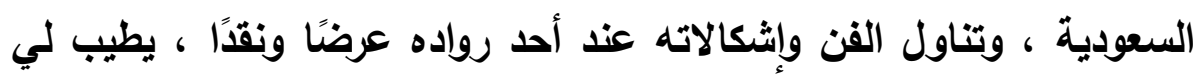
تدوين بعض النتائج: • المونودراما فن عصيّ يتأبّى إلا على كاتب متمكن من أدواته ، قادر

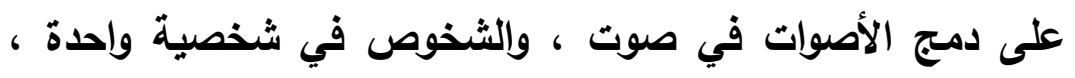

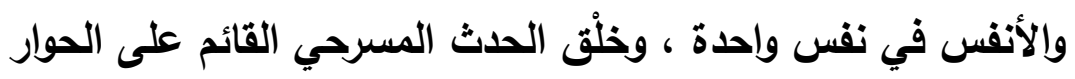

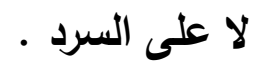

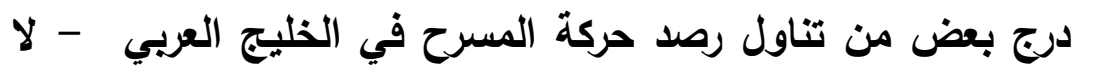
سيما المملكة العربية السعودية - على الخلط بين المسرحية 


$$
\text { والمسرح / المخطوط والمنفذ . }
$$

النسيئة في نشأة عروض الفن المسرحي في المملكة العربية

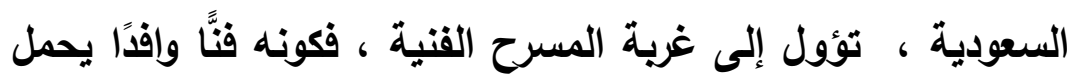
تصورًا معينًا عن منشئَه وبيئة منشئيهِ ، كان ذلك أدعى لرفض قبوله وتقبله وتذوقه ، لاى مجتمع رست في أذهان أفراده أنه نوع من الملهيات الماجنة ، التي لا يرجى درُّها .

نشطت عروض المونودراما المسرحية في المملكة العربية السعودية نشاطًا ملحوظًا ، في مرحلة متأخرة ، وخصصت لها المهرجانات والفاعليات ، وشغلت حيزًا في الساحة الإبداعية ، وكانت الانطلاقة الأولى من مدينة الطائف ، ومونودراما " صفعة في المرآة " لعبد

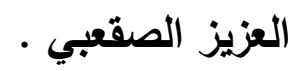

المونودراما غير قادرة إلى النفاذ في عمق المشهر المجتمعي ، ونقد أوضاعه أونقضها ، فطريقتها في التصادم مع السلبيات ملتوية تفتقر إلى المباشرة ، فتجنح إلى استخدام الأسلوب الساخر ، وطبيعتها الفردية / الانعزالية الاختزالية تحول دون إمكانية الطرح الثامل والمعالجة الكاملة لقضايا المجتمع. • الواقعية الفردية / الرومانسية أحد أهم مصادر فن المونودراما، وهذا يؤول إلى أن أركانها القنية قد اكتملت في رحاب الحركة الرومانسية ، التي نادت بتقديس النزعة القردية. المونودراما شكل من أشكال الفن المسرحي التجريبي ، وإن تباينت 


$$
\text { مونودراما المسرح السودى الروئية }
$$

درجات التعاطي معه ، وتتلك ظاهرة إيجابية ، إذ الفن المسرحي ينبغي

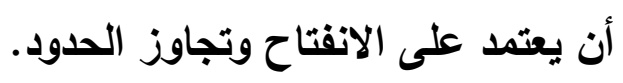

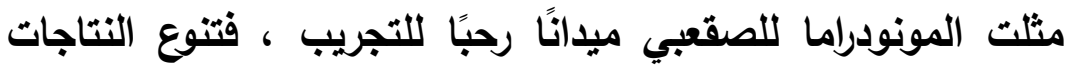

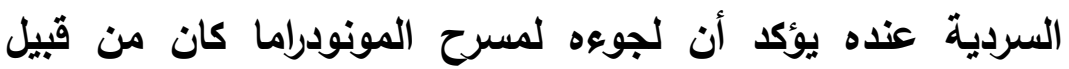
التنويع والتجريب الفني.

يؤخذ عليه أنه لم يبدأ في أحد نصوصه بقمة الحدث الارامي ، أو ما يطلق عليه " منطقة الهجوم " . مع مرونة الثكل المونودرامي عند الصقعبي ، إلا أنها ظلت بعيدة

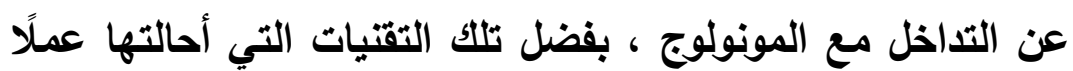
مسرحيًّ يتغلب على أحادية التعبير . استعان الصقعب بجملة من الوسائل الفنية ، التي عالج بها مشكلة وحدة الصراع والحوار، واستعاض عن الغائب باستحضاره وتمثله

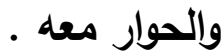




\section{فهربس المراجع}

• أزمة المسرح السعودي ، ياسر مدخلي ، دار ناشري للنشر الإليكتروني $\cdot p^{r} \cdot \mathrm{V}$

• إلى المسرح مع التحية .. مقالات ودراسات ، علي بن عبدالعزيز السعيد

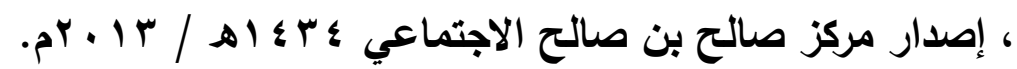
التيارات المسرحية المعاصرة ، نهاد صليحة ، الهيئة المصرية العامة

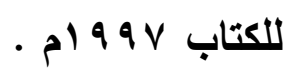
جماليات المكان ، غاستون باشلار ، ترجمة : غالب هلسا ، المؤسسة

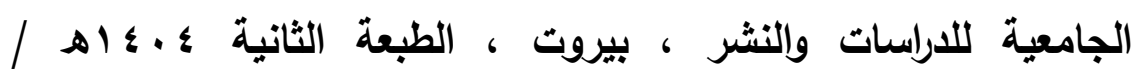
-p) $9 \wedge \varepsilon$

الجمعية العربية السعودية للثقافة والفنون .. وأربعون عاما من المسرح rq

$$
\text { هـ }
$$

الدراما والدرامية ، س . و ـ ـ داوسن ، ترجمة : جعفر الصادق الخليلي ،

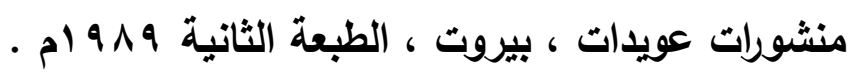
السلم في علم المنطق للأخضري ، تحقيق : عمر فاروق الطباع ، مكتبة

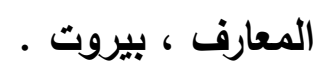

صفعة في المرآة ومسرحيات أخرى ، وزارة الثقافة والإعلام ، المملكة

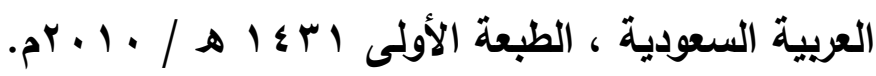
فلسفة المرآة ، محمود رجب ، دار المعارف المصرية ، الطبعة الأولى ، الطي 
• فن السينوغرافيا ومجالات الخبرة ، كراس [ السينوغرافيا اليوم ] ] ، مارسيل فريد نون ، ترجمة: إبراهيم حمادة وآخرون، وزارة الثقافة المصرية ، منشورات مهرجان القاهرة للمسرح التجريبي ، القاهرة - p) 994 الكتابة خارج الأقواس .. دراسات في الشعر والقصة ، سعيا السريحي،

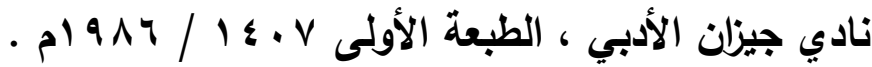

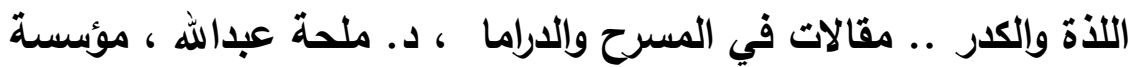

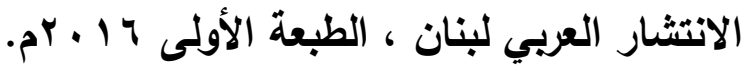
مدخل إلى دراسة المسرح في المملكة العربية السعودية ، ناصر عبدالعزيز الخطيب ، إصدارات المهرجان الوطني السعودي للتراث

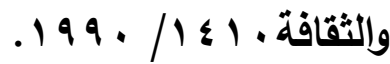
المسرح السعودي .. دراسة نقدية ، نذير العظمة ، الناشر النادي الأدبي

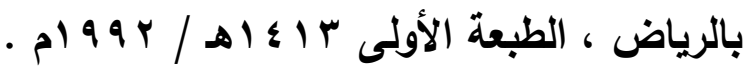
المسرح السعودي بين البناء والتوجس ، حليمة مظفر ، مطبوعات نادي الطائف الأدبي الثقافي بالتعاون مع دار شرقيات ، الطبعة الأولى $\cdot a^{r} \cdot a^{2}$ المسرح في المملكة العربية السعودية .. مسارات التطور واتجاهاته ، د. وطفاء حمادي ، طبعة الجمعية العربية السعودية للثقافة والقتون

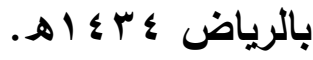


المسرح والقضايا المعاصرة ، يحيى البشتاوي ، الأكاديميون للنشر

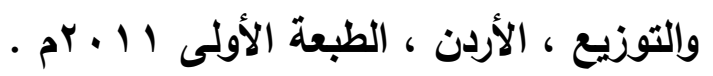

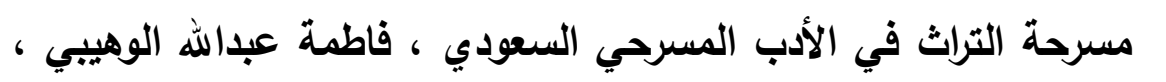

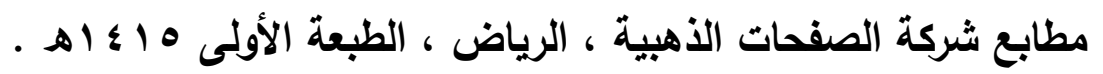
مسرحية " هاملت .. أمير دانمركة " ، شكسبير ، جامعة الدول العربية ، المنظمة العربية للتربية والثقافة والعلوم ، الطبعة الثالثة دار المعارف المصرية .

• المونودراما : مسرحية الممثل الواحد .. تجارب المونودراما في المشهر المسرحي العربي ، محمود أبو العباس ، مكتبة العبيكان ، الطبعة الأولى .

• نظرية العرض المسرحي ، جوليان هلتون ، تحقيق : نهاد صليحة ،

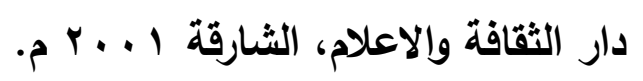
نظرية العرض المسرحي ، جوليان هلتون ، ترجمة : نهاد صليحة ، هلا

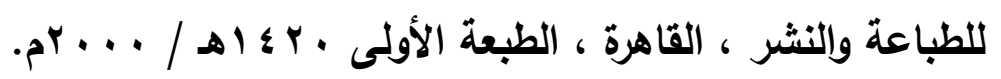

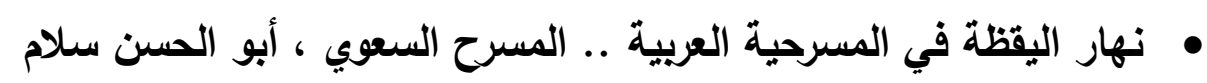
، دار الوفاء لانيا الطباعة والنشر الإسكندرية ، الطبعة الأولى ع . . ب م.

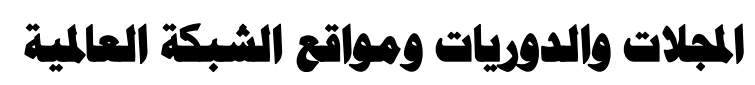
- مجلة البيان الإماراتية

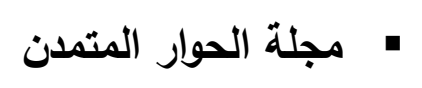
• مجلة العربي الكويتية

071 مجلة كلية اصول الدين والدعوة / العدد الخامس والثلاثتون V ا ـ ـ الجزء الاول 


$$
\text { مونودراما المسرح السعودى الروئية }
$$

$$
\begin{aligned}
& \text { • مجلة نقوش } \\
& \text { • جريدة الرياض لعاض } \\
& \text { (رابطة أدباء الثام: }
\end{aligned}
$$

http://www.odabasham.net/\%D9\%81\%D9\%86\%D9\%88

\%D9\%86/53381\%D8\%A7\%D9\%84\%D8\%B3\%D9\%8A\%D9\%86\%D9\%88. 